2001

\title{
Women Do Not Report the Violence They Suffer: Violence against Women and the State Action Doctrine
}

Michelle J. Anderson

Follow this and additional works at: https://digitalcommons.law.villanova.edu/vlr

Part of the Constitutional Law Commons

\section{Recommended Citation}

Michelle J. Anderson, Women Do Not Report the Violence They Suffer: Violence against Women and the State Action Doctrine, 46 Vill. L. Rev. 907 (2001).

Available at: https://digitalcommons.law.villanova.edu/vlr/vol46/iss5/1

This Symposia is brought to you for free and open access by Villanova University Charles Widger School of Law Digital Repository. It has been accepted for inclusion in Villanova Law Review by an authorized editor of Villanova University Charles Widger School of Law Digital Repository. 


\title{
VILLANOVA LAW REVIEW
}

VOLUME 46

2001

Number 5

\section{Symposium \\ New Voices on the New Federalism}

\section{WOMEN DO NOT REPORT THE VIOLENCE THEY SUFFER: VIOLENCE AGAINST WOMEN AND THE STATE ACTION DOCTRINE}

\author{
Michelle J. Anderson*
}

\section{INTRODUCTION}

$\mathrm{E}$ IGHTY-FOUR percent of women who are raped do not report the experience to the police. ${ }^{1}$ They simply do not seek a legal remedy. They understand the hard truth that state law and state actors-police, prosecutors and judges-ordinarily provide no legal remedy for violence that is motivated by gender animus.

In 1994, Congress tried to give women a remedy that did not rely on state law and state actors when it enacted $\S 13981$ of the Violence Against Women Act (VAWA). ${ }^{2}$ This provision of VAWA gave women the opportunity to lodge civil complaints against their attackers in federal court if they were subjected to criminal violence motivated by gender animus. In United States v. Morrison, ${ }^{3}$ however, the United States Supreme Court struck down the provision as unconstitutional. The Court declared that Congress lacked the authority to enact $\$ 13981$ of VAWA under either the Commerce Clause or section 5 of the Fourteenth Amendment.

This Article will not address the Supreme Court's Commerce Clause analysis in Morrison. Instead, the Article concentrates on the Supreme Court's analysis of congressional authority under section 5 of the Fourteenth Amendment. The Court held that section 5 provided Congress

* Assistant Professor, Villanova University School of Law. B.A. University of California at Santa Cruz, 1989; J.D. Yale Law School, 1994; LL.M. Georgetown University Law Center, 1997. I would like to thank Frank Cooper, Ann Juliano, Cathy Lanctot, Greg Magarian, Nazareth Pantaloni and Richard Turkington for their insight and critique. Polly Hayes and Erik Williams provided excellent research assistance. All errors are mine.

1. See Nat'l Victim Ctr., Rape in America: A Report to the Nation 5 (1992).

2. 42 U.S.C. $\$ 13981(1998)$.

3. 529 U.S. $598(2000)$. 
with no authority to enact $\S 13981$ of VAWA primarily because the amendment reaches only actions committed by state officials, not the actions of private individuals who commit violence against women. ${ }^{4}$

The requirement of state action under the Fourteenth Amendment, the state action doctrine, has been subjected to significant scholarly criticism. Some academics argue that certain kinds of private action should fall within the rubric of state action for purposes of the doctrine. ${ }^{5}$ Others have argued that the state action requirement should be abolished altogether. $^{6}$ Regardless of how persuasive one finds those arguments, one need not adopt either of them in order to find $\$ 13981$ in VAWA constitutional.

To understand the constitutionality of $\$ 13981$ in VAWA, one needs to examine the scope of the constitutional violation at issue when states

4. See Morrison, 529 U.S. at 621 ("[A]ction inhibited by the first section of the Fourteenth Amendment is only such action as may fairly be said to be that of the States. That Amendment erects no shield against merely private conduct, however discriminatory or wrongful.") (citing Shelley v. Kramer, 334 U.S. 1, 13 n.12 (1948)).

5. See, e.g., Alan R. Madry, Private Accountability and the Fourteenth Amendment; State Action, Federalism and Congress, 59 Mo. L. REv. 499, 512 (1994) (suggesting that Fourteenth Amendment should be read in conjunction with Privileges and Immunities Clause as creating state duty to intervene between private parties to protect fundamental interests). Although the Fourteenth Amendment's explicit language restricts the state from abridging these rights, Congress intended the amendment to protect against private encroachment by opening federal courts to actions directly against private parties that violated the rights of individuals. See id. at 547 (stating primary purpose of amendment was to legitimate Civil Rights Act of 1866 which defined some fundamental rights). Congress may create a private cause of action between private parties when, because the state is unwilling to protect the interest, the Supreme Court's review of state actions would provide inadequate protection. See id. (quoting and refuting dicta that states amendment "erects no shield against merely private conduct, however discriminatory or wrongful") (citation omitted); see also Robert J. Glennon, Jr. \& John E. Nowak, A Functional Analysis of the Fourteenth Amendment "State Action" Requirement, 1976 SuP. CT. REv. 221, 231 (suggesting balancing test to weigh competing rights in context of Fourteenth Amendment protection). If an alleged deprivation violates the amendment and the deprivation occurs because the state maintains a legal system which legitimates or tolerates the deprivation, the state can be said to have chosen the practice that creates the deprivation as a superior right. See id. at 230 (noting method of state to deprive person of right to due process). Confronted with this conflict, the court must determine whether the Fourteenth Amendment dictates a preference for one right over the other, i.e., the right to engage in the practice that causes the deprivation over the right to be free from the deprivation. See id. at 221 (explaining appropriate inquiry); see also Charles L. Black, Jr., "State Action," Equal Protection and California's Proposition 14, 81 HARv. L. REv. 69, 70 (1967) (criticizing Supreme Court's formulation of state action doctrine).

6. See Erwin Chemerinsky, Rethinking State Action, 80 Nw. U. L. Rev. 503, 505 (1985) ("I suggest that it is time to begin rethinking state action. It is time to again ask why infringements of the most basic values-speech, privacy, and equalityshould be tolerated just because the violator is a private entity rather than the government."). See also Paul Brest, State Action and Liberal Theory: A Casenote on Flagg Brothers v. Brooks, 130 U. PA. L. Rev. 1296, 1297 (1982) (using natural law theory to argue for abolition of state action requirement). 
address violence against women. Imagine an average rape victim. She is drinking with friends at a party when an acquaintance gets her alone and becomes sexually aggressive. ${ }^{7}$ She begins to cry. Despite her tears and repeated no's, he pins her down and rapes her. Like most rape victims, she suffers little injury extrinsic to the rape itself. ${ }^{8}$ She has no bruises or other corroborative evidence, but she wants to die inside. If she calls the police, officials may disbelieve her and code the case as "unfounded" (a false complaint). ${ }^{9}$ Or police may bury her complaint by logging it with a non-criminal code, where it will receive little to no investigation..$^{10}$ Police also may encourage her to withdraw the complaint. If police do choose to investigate and arrest her attacker, prosecutors nevertheless may choose not to indict him because the victim failed to complain promptly enough, failed to resist her attacker forcefully enough or failed to lead her prior sexual life virtuously enough. ${ }^{11}$ These discretionary decisions by state actors have their roots in earlier statutes and the common law when corroboration, fresh complaint, utmost resistance and chastity on the part of the victim were more formally required. If our hypothetical acquaintance rape victim manages to make it to the trial stage of the process, she will be subjected to cross examination that includes a detailed scrutiny of her prior sexual history with the assailant offered to prove that she consented and is now lying. Therefore, if this victim reports having been raped to the police, she will be subjected to a humiliating process-the laws and legal procedures that constitute what some scholars have called the "second rape."12 Ordinarily, she also will receive no legal redress for the wrong against her. ${ }^{13}$ On the other hand, if the victim does not report having been raped to the police, she will receive no legal redress, but she will manage to avoid the penalties that often befall those who do report. It is not surprising, therefore, that most victims do not report having been raped to the police.

7. For a discussion of the prevalence of acquaintance rape, see infra notes 7176 and accompanying text.

8. For a discussion of the non-physical harm caused by rape, see infra notes 77-84 and accompanying text. text.

9. For a discussion of "unfounding," see infra notes 116-36 and accompanying

10. For a discussion of police discretion, see infra notes $137-45$ and accompanying text.

11. For a discussion of prosecutorial discretion, see infra notes $146-61$ and accompanying text.

12. See Lee Madigan \& Nancy Gamble, The Second Rape: Society's Continued Betrayal of THE Victim (1991) (discussing theory of "second rape"); see also Martin S. Greenberg \& R. Barry Ruback, After the Crime: Victim Decision MAKING 7 (1992) (describing "second injury" phenomenon). Unsympathetic justice officials and defense attorneys can exacerbate the stress and discomfort caused by the initial victimization. See id. (discussing problems for victims reporting cases).

13. For a discussion of rape victims' lack of legal redress, see infra notes 14770 and accompanying text. 
Section 1 of the Fourteenth Amendment says, "No state shall . . deny to any person within its jurisdiction the equal protection of the laws." 14 Section 5 of the Fourteenth Amendment gives Congress "the power to enforce, by appropriate legislation, the provisions of this article." 15 Women's rights under section 1 of the Fourteenth Amendment are violated by states' unwillingness to provide women with equal legal protection against violence that is motivated by gender animus. Section 1 affords women the right to be free from this kind of gender discrimination. ${ }^{16}$

In response to states' pervasive and systematic denial of equal protection, women have little to no faith in the formal structures of police power to remedy violence motivated by gender animus. As a result, the vast majority of women do not report to police when they are raped or battered. ${ }^{17}$ Thus, the reality of state action extends beyond whether state actors respond poorly to any individual woman who alleges having been beaten or raped. States in fact deter women from turning to their authority because the protection they offer is unequal and often illusory.

The fact that state laws and procedures deter victims from reporting has consequences for what remedies Congress is authorized to enact under section 5 of the Fourteenth Amendment in order to enforce women's equal protection rights in this context. Because the states' denial of equal protection inhibits women from reporting, reporting itself cannot be a condition precedent to obtaining relief under section 5 . When states' laws and procedures deter women from reporting the violence they suffer, states have acted to deny equal protection. Nevertheless, when a woman does not report, there is no state actor she can sue for the equal protection violation. ${ }^{18}$ Congress should therefore be authorized under section 5 to remedy the violation of her equal protection rights by providing her with the opportunity to make a civil claim against the individual who committed the crime motivated by gender animus. Only if section 5 autho-

14. U.S. Const. amend. XIV, $\S 1$. Section 1 of the Fourteenth Amendment provides that:

No State shall make or enforce any law which shall abridge the privileges or immunities of citizens of the United States; nor shall any State deprive any person of life, liberty, or property, without due process of law; nor Id.

deny to any person within its jurisdiction the equal protection of the laws.

15. U.S. Const. amend. XIV, $\S 5$. Section 5 of the Fourteenth Amendment gives Congress the "power to enforce, by appropriate legislation, the provisions of" article I. Id.

16. For a discussion of the section 1 violation, see infra notes 220-23 and accompanying text.

17. Women who are battered likewise do not ordinarily report their violence to the state. See Planned Parenthood of Southeastern Penn. v. Casey, 505 U.S. 833, 889 (1992) (noting district court's finding that secrecy typically shrouds abusive families and that victims do not report abuse). "Researchers estimate that one in every two women will be battered at some time in their life." Id. at 888 .

18. Even if she could sue a state actor, it would be very difficult for her to obtain relief under the relevant doctrines of $\S 1983$. 
rizes this remedial help will the Fourteenth Amendment be able to address state malfeasance regarding violence against women.

The argument here does not rely on a notion that the state is encouraging violence against women, although one could argue that states do encourage it because they fail to prosecute it vigorously. The argument does not depend on the notion that there is a symbiotic relationship between the private violence at issue here and state action, although one could argue that there is in the case of violence against women. This argument assumes nothing new about how courts should measure a violation of section 1 of the Fourteenth Amendment in relation to violence against women. Congress found that states deny women equal protection of the law through state laws and the discretionary decisions and practices of state actors, such as police, prosecutors and judges. ${ }^{19}$ What is new here is an understanding of what section 5 authorizes once states' violations of section 1 deter women from engaging the state altogether. Because rational actors do not choose to report to the state when to do so would be futile, Congress is not limited under section 5 to remedying only those cases in which women do report to the state. Rather, Congress has the authority under section 5 to attack the real problem-the pervasive denial of a legal remedy for women who suffer crimes motivated by gender animus. When states' violations of section 1 deter women from reporting, Congress may provide a legal remedy in the form of civil claims against private actors. Section 5 of the Fourteenth Amendment gives Congress the "power to enforce by appropriate legislation," section 1's commitment to equal protection. ${ }^{20}$ Section 13981 in VAWA is the most appropriate legislation to enforce the provisions of section 1 of the Fourteenth Amendment in this context.

Part II of this Article describes the Morrison facts and the Supreme Court's analysis of the section 1 violation. ${ }^{21}$ Part III reviews the full scope of the section 1 violation, both historically and currently. ${ }^{22}$ It argues that, historically, explicit requirements in rape law evinced profound gender bias and that, although those requirements have been formally abolished in the past few decades, they continue to direct the discretionary decisions of state actors. Specifically, as a result of the biased imperatives behind the historical requirements in rape law, police disproportionately "unfound" rape complaints, place the complaints in non-criminal codes and discourage women from proceeding with their complaints. Additionally, prosecutors disproportionately dismiss rape cases because of the same biased imperatives. As a result of anticipating futile and humiliating interac-

19. For a discussion of discretionary practices, see infra notes $116-81$ and accompanying text.

20. U.S. ConsT. amend. XIV, $\S 5$.

21. For an examination of the facts in Morrison and the Supreme Court's section 1 analysis, see infra notes 25-66 and accompanying text.

22. For a discussion of the historical and modern breadth of the section 1 violation, see infra notes $67-187$ and accompanying text. 
tions with state actors if they do report, rape victims overwhelmingly do not report the violence they suffer. Part IV examines the Supreme Court's analysis of congressional authority under section 5 to enact the civil remedy provision in VAWA. ${ }^{23}$ It argues that the Court misunderstood the full scope of the section 1 violation and was thereby misguided in its analysis of the appropriate, congruent and proportional remedial measures authorized under section 5 in response to it. Part V concludes that VAWA provides a congruent and proportional legal remedy to the Fourteenth Amendment violations suffered by women. ${ }^{24}$

\section{UNTTED STATES V. MORRISON}

On September 21, 1994, Christy Brzonkala, a student at Virginia Polytechnic Institute (Virginia Tech), met Antonio Morrison and James Crawford, two Virginia Tech football players, in the dorm where she lived. ${ }^{25}$ Shortly thereafter, Crawford left with one of Brzonkala's friends. Morrison immediately asked Brzonkala to have sexual intercourse with him. She said "no." Morrison asked again, and again she said "no."26 Brzonkala tried to leave the room, but "Morrison grabbed her, and threw her, face-up, on a bed ... he pushed her down by the shoulders and disrobed her." 27 Brzonkala struggled to get free, but Morrison pinned her with his arms and legs and forcibly raped her. ${ }^{28}$ Before she could escape, Crawford then entered the room, pinned Brzonkala with his arms and legs and forcibly raped her. After Crawford had finished, Morrison then raped Brzonkala a second time. Morrison warned Brzonkala after these three rapes that she "better not have any fucking diseases." 29 In the following months, Morrison boasted in the dorm dining hall that he "like[d] to get girls drunk and fuck the shit out of them."30

After this experience, Brzonkala's behavior changed dramatically. She stopped attending classes, suffered depression and attempted suicide. ${ }^{31}$ One month after the rapes, Brzonkala disclosed to her roommate

23. For a discussion of the Supreme Court's section 5 analysis with regard to VAWA, see infra notes 188-236 and accompanying text.

24. For an argument that VAWA provides a congruent and proportional legal remedy to Fourteenth Amendment violations suffered by women, see infra note 237 and accompanying text.

25. See Brzonkala v. Va. Polytechnic Inst. \& State Univ., 132 F.3d 949, 953 (4th

Cir. 1997) (describing facts contained in Brzonkala's complaint).

26. See id. (explaining that Brzonkala twice refused Morrison's sexual advances).

27. See id. (describing rape).

28. See id. (noting Brzonkala's non-consent).

29. Id.

30. Id.

31. See id. (describing Brzonkala's behavioral changes after incident with Morrison). Brzonkala sought treatment from a school psychiatrist who prescribed an anti-depressant, but made only cursory attempts to discover the source of her depression. See id. (discussing Brzonkala's trauma and eventual withdrawal from school). 
that she had been raped, but could not discuss the details of the experience. ${ }^{32}$ Some months later, Brzonkala identified Morrison and Crawford as her assailants by using the Virginia Tech football guide. She did not call the police to report the crime, however, believing that "criminal prosecution was impossible because she had not preserved any physical evidence of the rape." 33

In May of 1995, Brzonkala filed a rape complaint against Morrison and Crawford under Virginia Tech's Sexual Assault Policy. Virginia Tech officials did not report Brzonkala's rapes to the police because "[r]ape of a female student by a male student is the only violent felony that Virginia Tech authorities do not automatically report to the university or town police." 34 Virginia Tech authorities additionally did not urge Brzonkala herself to report the rapes to the police. ${ }^{35}$

Virginia Tech's Judicial Committee held a hearing on Brzonkala's charges. At the hearing, Morrison admitted that, despite the fact that Brzonkala twice told him "no," he proceeded to have intercourse with her. ${ }^{36}$ Crawford denied having sexual intercourse with Brzonkala, but corroborated that Morrison did. ${ }^{37}$ Although the Committee found the evidence against Crawford insufficient, it found Morrison guilty of sexual assault. ${ }^{38}$ The Committee suspended Morrison for the Fall 1995 and Spring 1996 semesters. Morrison appealed to the Dean of Students, who affirmed the suspension and confirmed this decision in writing to Brzonkala. $^{39}$

Morrison then threatened to sue the university. ${ }^{40}$ The Dean of Students informed Brzonkala that, because Virginia Tech was unwilling to defend Morrison's one-year suspension in court, the school had decided to hold a second hearing on the charges. ${ }^{41}$ The Dean assured Brzonkala

32. See id.

33. Id. at 954 .

34. Id.

35. See id.

36. See United States v. Morrison, 529 U.S. 598, 603 (2000) ("Morrison admitted having sexual contact with her despite the fact that she had twice told him 'no.'").

37. See Brzonkala, 132 F.3d at 954 (discussing assertion by Crawford's alibi witness-another Virginia Tech football player-that Crawford did not have intercourse with Brzonkala).

38. See id.

39. See id.

40. See id. (discussing denial of due process claims made against Virginia Tech by Morrison's attorney).

41. See id. The school officials informed Brzonkala that "there might be merit to Morrison's 'ex post facto' challenge that he was charged under a Sexual Assault Policy that was not yet spelled out in the Student Handbook." Id. The officials also told Brzonkala that the school would hold a second hearing, under the school's previous Abusive Conduct Policy, because "Virginia Tech was unwilling to defend the school's decision to suspend Morrison for a year in court." Id. Brzonkala was told that the second hearing was "a mere technicality" because the officials "believed [Brzonkala's] story." Id. The second hearing turned out to be much more 
that this re-hearing was, a "mere technicality." 42 In preparation for the second hearing, Virginia Tech officials gave the recordings and transcripts of the first hearing to Morrison's attorney, but withheld them from Brzonkala's attorney. ${ }^{43}$

After the second hearing, the Committee found Morrison guilty of "using abusive language," not sexual assault, and it re-imposed a suspension. ${ }^{44}$ Morrison again appealed the suspension. ${ }^{45}$ The Vice-President of Virginia Tech then withdrew the punishment imposed, finding that it was "excessive when compared with other cases where there has been a finding of a violation" of the student code of conduct. ${ }^{46}$ The Vice-President required, instead, that Morrison attend a one-hour educational session on Virginia Tech's student policies. ${ }^{47}$ There was no letter from Virginia Tech officials this time informing Brzonkala of Virginia Tech's decision to set

than a "mere technicality;" it lasted more than twice as long as the first hearing and required Brzonkala to provide and pay for her own attorney. See id. at $954-55$ (discussing second hearing).

42. See id. at 954 (describing conversation between Dean and Brzonkala); see also Margo L. Ely, Civil Rights Law Withstands Early Constitutional Test, CHI. DAILY L. Bull., Feb. 9, 1998, at 6 (noting Dean's conversation with Brzonkala concerning second hearing).

43. See Brzonkala, 132 F.3d. at 955 (elaborating on Virginia Tech's cooperation with Morrison in preparation for second hearing). School officials informed Morrison, with ample notice, that testimony from the first hearing would not be admitted, that live witnesses or sworn affidavits were required at the second hearing and provided him with "complete and early access" to the tape recordings of the first hearing. See id. (highlighting school's assistance to Morrison in preparation for second hearing). In contrast, Virginia Tech "belatedly" informed Brzonkala that the testimony from the first hearing would be inadmissible. See id. at 954-55 (indicating school's lack of assistance to Brzonkala in preparation for second hearing). Because the second hearing took place during the summer, Brzonkala did not have time to locate her witnesses or to produce sworn affidavits from them. See id. at 955 . Virginia Tech officials also prevented Brzonkala from recounting her entire version of the assault; the school required her to leave out any mention of Crawford because the charges against him had been dismissed in the first hearing. See id. ("[A]s a result she had to present a truncated and unnatural version of the facts.").

44. See United States v. Morrison, 529 U.S. 598, 603 (2000) ("This time, however, the description of Morrison's offense was, without explanation, changed from 'sexual assault' to 'using abusive language.'"). Neither Brzonkala nor her attorney knew of the reduction in charges against Morrison. See Brzonkala, 132 F.3d at 955-56 (discussing reduction of charges). Brzonkala learned of the "abusive language" charge through a newspaper article. See id.

45. See Brzonkala, 132 F.3d at 955 ("He argued due process violation, the existence of new information, and the asserted harshness and arbitrariness of the sanction imposed on him as grounds for reversal of the judicial committee's decision.").

46. Morrison, 529 U.S. at 603. Judge Mott criticized the Vice-President of Virginia Tech for "not elaborat[ing] on the 'other cases' to which she" compared Morrison's punishment. See Brzonkala, 132 F.3d at 955 (noting no cases cited).

47. See Morrison's Suspension Was For Abusive Language, Virginian-Pilot (Norfolk), Dec. 8, 1995, at Cl (defining “'deferred' suspension, meaning the suspension would take effect immediately if found guilty of another offense by the [Virginia Tech] Judicial System"). 
aside Morrison's suspension. In fact, Brzonkala learned that Morrison would be returning to Virginia Tech on a full athletic scholarship from an article in the Washington Post. ${ }^{48}$ Brzonkala did not return to Virginia Tech that semester because she was afraid of running into Morrison. ${ }^{49}$

In December of that year, Brzonkala sued Morrison and Crawford under $\S 13981$ of VAWA in the United States District Court for the Western District of Virginia. ${ }^{50}$ Brzonkala alleged that Morrison and Crawford

48. See Brzonkala, 132 F.3d at 955 (stating that school withheld information from Brzonkala, despite having kept her informed at every other step in process). Virginia Tech officials declined to inform Brzonkala that Morrison's suspension had been lifted and that he would be returning to campus for the fall semester. See $i d$. (detailing school's withholding of information). Brzonkala learned in an August 22, 1995 newspaper article that Morrison was returning to Virginia Tech to play football. See id. Brzonkala did not learn until November 30, 1995, again through a newspaper article, that the second school hearing found Morrison guilty of the "reduced charge of "using abusive language" rather than "sexual assault." Id. at 955. Despite the fact that the school officials who visited Brzonkala at her home assured her that the second hearing would "address the 'sexual assault' charge against Morrison, the administrators altered the charge." Id. at 955-56 (stating that school neglected to notify both Brzonkala and her attorney).

49. See id. (noting Brzonkala's fear for her safety because of threats and school's treatment of Morrison). Brzonkala was dismayed that Morrison was able to continue his education at Virginia Tech. See Morrison's Suspension Was for Abusive Language, supra note 47 (quoting Brzonkala, "[h]e's living his life like he wants to, and I'm suffering").

After his suspension was deferred, Morrison returned to play football at Virginia Tech for the 1995 season. See Brzonkala, 132 F.3d at 955 (discussing facts of case). A highly recruited sophomore, Morrison later was suspended from the football team by the head coach "for failure to live up to the standards set for Virginia Tech football players." Allison Blake, Tech Team Suspends 2 Players; Failure to Live up to Standards, Roanoke Times \& World News, Dec. 13, 1995, at A1 (discussing Morrison's subsequent arrest for public drunkenness and petty larceny); see also Allison Blake, Athlete Fined for Bar Incident, Roanoke Times \& World News, Feb. 16, 1996, at C3 [hereinafter Athlete Fined] (discussing charges of "petty larceny, destruction of property, public intoxication, and possession of false identification"). Morrison returned the money he removed from the bar's tip jar and participated in an alcohol education program. See Athlete Fined, supra (discussing outcome of case).

After Morrison was excluded from the Virginia Tech football team in March 1996, he transferred to Hampton University to finish his college football career. See Ed Miller, Morrison Starts New Football Life at Hampton; The Linebacker Is Hoping to Leave Troubled Past Behind, Virginian-Pilot (Norfolk), Aug. 29, 1997, at C8 (stating that Virginia Tech coaches felt Morrison was "a victim of circumstances" who "deserved a second chance"). Morrison's second chance has proved successful; he played the 2000 season in the professional Arena Football 2 League. See Jeff Hartsell, Foxes Drop (Kick) a Close One, 39-38, Post \& Courier (Charleston, S.C.), Apr. 23, 2000, at C1 (discussing Morrison's achievements in spring game).

50. See Brzonkala, 132 F.3d at 956 (discussing procedural history of case). On March 1, 1996, she amended her complaint. She alleged that Virginia Tech violated Title IX of the Education Amendments of 1972, 20 U.S.C. $\$ \$ 1681-1688$ (1994), because of the university's faulty handling of the rape charges and its failure to punish the rapists in "any meaningful manner." See id. (describing amended complaint and citing to 20 U.S.C. $\$ \$ 1681-88$ (1994)). On May 7, 1996, the district court dismissed the Title IX claims against Virginia Tech for a failure to state a claim on which relief could be granted. See id. (citing Brzonkala v. Va. 
had subjected her to criminal violence motivated by gender animus and she sought vindication of her rights under VAWA.51 The United States intervened to defend the constitutionality of the statute. ${ }^{52}$ The district court dismissed Brzonkala's claim on the ground that Congress had exceeded its constitutional authority in enacting $\S 13981$ of VAWA. ${ }^{53}$ When the case reached the Supreme Court, ${ }^{54}$ the Court agreed. ${ }^{55}$

In enacting $\$ 13981$ of VAWA, Congress had relied on its power under both the Commerce Clause ${ }^{56}$ and section 5 of the Fourteenth Amendment. ${ }^{57}$ Many scholars have argued that Morrison marks a substan-

Polytechnic Inst. \& State Univ., 935 F. Supp. 772 (W.D. Va. 1996)). The district court held, and the en banc court of appeals affirmed, that Brzonkala failed to state a claim of disparate treatment under Title IX. See Morrison, 529 U.S. at 604 n.2. The en banc court of appeals vacated the district court's dismissal of Brzonkala's hostile environment claim against Virginia Tech pending a United States Supreme Court decision on the same issue in a case in which the Court had already granted certiorari. See id. Brzonkala eventually settled her case with Vir-

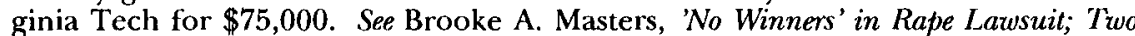
Students Forever Changed by Case That Went to the Supreme Court, WASH. Post, May 20, 2000, at METRO (describing settlement).

51. See Brzonkala, 132 F.3d at 953-56 (discussing facts of Brzonkala's complaint). Because the case was decided on a motion to dismiss, the courts viewed the facts alleged in Brzonkala's complaint as true. The United States Supreme Court cited sparingly to Brzonkala's complaint for support of the factual allegations, drawing instead on Judge Mott's panel opinion in the United States Court of Appeals for the Fourth Circuit. Compare Morrison, 529 U.S. at 601-06 (stating facts and procedural history of case), with Brzonkala, 132 F.3d at 953-56 (same).

52. See Morrison, 529 U.S. at 604 (explaining procedural posture of case).

53. See id. at 604-05 (stating holding of lower court).

54. On December 23, 1997, a panel of the United States Court of Appeals for the Fourth Circuit reversed the District Court's decision regarding Brzonkala's $\S 13981$ claim. See id. at 604-05 (stating the holding of the panel). The panel also reinstated Brzonkala's Title IX hostile environment claim against Virginia Tech. See id. (discussing holding of Fourth Circuit panel decision). An en banc court of the Fourth Circuit then vacated the panel's decision, and on May 5, 1999, the en banc court affirmed the district court's opinion that Brzonkala had stated a claim under $\S 13981$, but that Congress did not have the constitutional authority to enact that provision of VAWA. See id. at 604-05 (concluding that Brzonkala "stated a claim under $\S 13981$ because her complaint alleged a crime of violence and the allegations of Morrison's crude and derogatory statements regarding his treatment of women sufficiently indicated that his crime was motivated by gender animus"). The court then determined that Congress exceeded its authority under the Constitution when enacting a civil rights remedy against the private actors. See id. at 604 05 (stating second holding of en banc court).

55. See id. at 627 (concluding that "Congress' power under $\$ 5$ does not extend to the enactment of $\$ 13981 ")$.

56. See U.S. ConsT. art. I, $\$ 8$ (defining Congress' power " $[\mathrm{t}]$ o regulate Commerce with foreign Nations, and among the several States, and with the Indian Tribes"). Congress expressly relied on the Commerce Clause and the Fourteenth Amendment. See Morrison, 529 U.S. at 607 (discussing Congress' claim of authority to enact $\$ 13981$ (quoting 42 U.S.C. \$13981(a) (1998))).

57. See U.S. Const. amend. XIV, \$5 ("The Congress shall have power to enforce this article by appropriate legislation."); Morrison, 529 U.S. at 619 (noting Congress' claim of authority under section 5 of Fourteenth Amendment). Section 13981 states: 
tive shift in Commerce Clause doctrine ${ }^{58}$ and was, wrongly decided under the relevant precedent. ${ }^{59}$ I agree with that view; however, I will set aside

Pursuant to the affirmative power of Congress to enact this part under section 5 of the Fourteenth Amendment to the Constitution, as well as under section 8 of Article I of the Constitution, it is the purpose of this part to protect the civil rights of victims of gender-motivated violence and to promote public safety, health, and activities affecting interstate commerce by establishing a Federal civil rights cause of action for victims of crimes of violence motivated by gender.

42 U.S.C. $\$ 13981$ (a) (1994).

58. After Morrison, rather than being able to regulate just about anything that substantially affects interstate commerce, Congress is limited to regulating those activities that are primarily economic in nature. Notice that violence against some women is economic in nature. For example, violence against prostituted women committed by pimps or johns during the course of business occurs in a setting defined by an economic relationship between the parties. Studies indicate that sixty-eight percent of prostitutes have been raped while working as prostitutes. See Melissa Farley \& Howard Barkan, Prostitution, Violence, and Posttraumatic Stress Disorder, 27 WOMEN \& HEALTH 37, 40-41 (1998). Of those who were raped, forty-eight percent had been raped more than five times. See id. Eighty-two percent of prostitutes have been physically assaulted while working as prostitutes. See id. Forty-six percent of those who report having been raped were raped by their customers. See $i d$. at 41 . Interviews of 475 prostitutes in five countries (South Africa, Thailand, Turkey, U.S.A. and Zambia) came to similar conclusions. See Melissa Farley et al., Prostitution in Five Countries: Violence and Posttraumatic Stress Disorder, 8 FEminism \& Psychol. 405, 414 tbl. 4 (1998). Sixty-two percent report having been raped since entering prostitution. See id. Of those who were raped, forty-six percent had been raped more than five times. See id. Prostitution's effect on interstate commerce is not insubstantial. Because prostitution is an economic activity, Congress could regulate violence against prostituted women under the Commerce Clause, and it might choose to do so because states rarely pursue criminal charges against those who violate prostituted women.

59. See Victoria F. Nourse, Where Violence, Relationship, and Equality Meet: The Violence Against Women Act's Civil Rights Remedy, 15 Wis. WOMEN's L.J. 257, 274-92 (2000) (discussing legislative history detailing congressional responses to constitutional challenges during passage of VAWA); Margaret A. Cain, Comment, The Civil Rights Provision of the Violence Against Women Act: Its Legacy and Future, 34 TULSA L.J. 367, 399-407 (1999) (arguing that $\$ 13981$ is constitutional exercise of Congress' Commerce Clause power); Christine M. Devey, Note, Commerce Clause, Enforcement Clause, or Neither? The Constitutionality of the Violence Against Women Act in Brzonkala v. Morrison, 34 U. RICH. L. Rev. 567, 581-87 (2000) (arguing that $\$ 13981$ should be upheld as valid exercise of Congress' Commerce Clause power); Parker Douglas, Note, The Violence Against Women Act and Contemporary Commerce Power: Principled Regulation and the Concerns of Federalism, 1999 Utah L. REv. 703, 722-53 (same); Sara E. Kropf, Note, The Failure of United States v. Lopez: Analyzing the Violence Against Women Act, 8 S. Cal. Rev. L. \& Women's Stud. 373, 395-412 (1999) (same); Judi L. Lemos, Comment, The Violence Against Women Act of 1994: Connecting Gender-Motivated Violence to Interstate Commerce, 21 SeATtLe U. L. REv. 1251, $1267-76$ (1998) (same); Peter J. Liuzzo, Comment, Brzonkala v. Virginia Polytechnic and State University: The Constitutionality of the Violence Against Women Act-Recognizing That Violence Targeted at Women Affects Interstate Commerce, 63 Brook. L. Rev. 367, 385-93 (1997) (same); Charis Mincavage, Comment, Title III of the Violence Against Women Act: Can It Survive a Commerce Clause Challenge in the Wake of United States v. Lopez?, 102 Dick. L. Rev. 441, 459-70 (1998) (same); Megan Weinstein, Note, The Violence Against Women Act After United States v. Lopez: Defending the Act from Constitutional Challenge, 12 BerkeLey WOMEN's L.J. 119, 123-30 (1997) (defending VAWA 
the Court's analysis of congressional authority under the Commerce Clause and focus instead on its analysis of congressional authority to enact $\S 13981$ of VAWA under the Fourteenth Amendment. ${ }^{60}$

Section 1 of the Fourteenth Amendment prohibits a state from denying "to any person within its jurisdiction the equal protection of the laws." 61 Section 5 of the Fourteenth Amendment gives Congress "the

under Commerce Clause rationale). See generally Senator Joseph R. Biden, Jr., The Civil Rights Remedy of the Violence Against Women Act: A Defense, 37 HaRv. J. ON Legrs. 1 (2000) (defending civil rights remedy of VAWA as valid exercise of Congress' Commerce Clause and Equal Protection Clause authority).

Other scholars have defended VAWA on other grounds. See, e.g., Jordan J. Paust, Human Rights Purposes of the Violence Against Women Act and International Law's Enhancement of Congressional Power, 22 Hous. J. INT'L L. 209, 209-21 (2000) (utilizing principles of international law to support VAWA); Marcellene Elizabeth Hearn, Comment, $A$ Thirteenth Amendment Defense of the Violence Against Women Act, $146 \mathrm{U}$. PA. L. Rev. 1097, 1144-45 (1998) (analogizing plight of women to slavery and defending VAWA under Thirteenth Amendment's prohibition of slavery); Sarah B. Lawsky, Note, A Nineteenth Amendment Defense of the Violence Against Women Act, 109 YALE L.J. 783, 796-815 (2000) (arguing that VAWA is constitutional under Nineteenth Amendment's implied rights of full citizenship). But see Lisa A. Carroll, Comment, Women's Potverless Tool: How Congress Overreached the Constitution With the Civil Rights Remedy of the Violence Against Women Act, 30 J. Marshal. L. Rev. 803, 82034 (1997) (arguing that VAWA is unconstitutional); Troy Robert Rackham, Note, Enumerated Limits, Normative Principles, and Congressional Overstepping: Why the Civil Rights Provision of the Violence Against Women Act Is Unconstitutional, 6 WM. \& MARY J. WOMEN \& L. 447, 460-84 (2000) (same).

60 . There is a significant argument to be made that civil rights legislation should come under the rubric of the Fourteenth Amendment instead of the Commerce Clause. As Professor Jack Balkin has argued, "The Fourteenth Amendment is the natural home of civil rights legislation. It guarantees equal citizenship, and it gives Congress power to enforce equality rights." Jack M. Balkin, The Court Defers to a Racist Era, N.Y. Times, May 17, 2000, at A23.

Justice Douglas had stated that the Fourteenth Amendment was a preferable source of congressional authority for the major civil rights legislation of the 1960s. See Heart of Atlanta Hotel, Inc. v. United States, 379 U.S. 241 , 279 (1964) (Douglas, J., concurring) (stating that "the right of people to be free of state action that discriminates against them because of race ... 'occupies a more protected position in our constitutional system than does the movement of cattle, fruit, steel and coal across state lines"'). Douglas argued that the Civil Rights Act of 1964 was "much more obvious as a protective measure under the Fourteenth Amendment than under the Commerce Clause" because the "former deals with the constitutional status of the individual not with the impact on commerce of local activities or vice versa." Id. Justice Douglas stated emphatically: "our decision should be based on the Fourteenth Amendment, thereby putting an end to all obstructionist strategies and allowing every person-whatever his race, creed, or color-to patronize all places of public accommodation without discrimination whether he travels interstate or intrastate." Id. at 286. Justice Goldberg agreed, noting that the purpose of the Civil Rights Act of 1964 was "the vindication of human dignity and not mere economics." Id. at 291 (Goldberg, J., concurring).

61. U.S. Const. amend. XIV, $\$ 1$. Section 1 of the Fourteenth Amendment provides that:

No State shall make or enforce any law which shall abridge the privileges or immunities of citizens of the United States; nor shall any State deprive any person of life, liberty, or property, without due process of law; nor deny to any person within its jurisdiction the equal protection of the laws. 
power to enforce, by appropriate legislation" the rights enumerated in section $1 .^{62}$ In Morrison, the Court did not discuss at length the section 1 violation posed by the case. ${ }^{63}$ It appears the Court agreed that the State's response to violence against women constituted a violation of section $1 .{ }^{64}$ The Court noted that a "voluminous congressional record" supported the conclusion that "there is pervasive bias in various state justice systems against victims of gender-motivated violence." 65 The Court then briefly described the congressional findings:

Congress received evidence that many participants in state justice systems are perpetuating an array of erroneous stereotypes and assumptions. Congress concluded that these discriminatory stereotypes often result in insufficient investigation and prosecution of gender-motivated crime, inappropriate focus on the behavior and credibility of the victims of that crime, and unacceptably le-

Id.

62. U.S. Const amend. XIV, \$ 5 . Section 5 of the Fourteenth Amendment gives Congress the "power to enforce, by appropriate legislation, the provisions of" Article I. Id.

63. See Catharine MacKinnon, Disputing Male Sovereignly: On United States v. Morrison, 114 HARV. L. Rev. 135, 152 (2000) (criticizing invalidation of VAWA as Supreme Court's most damaging ruling on state action). Based on an extensive congressional record documenting both absent and inadequately applied state law against gender-motivated violence, VAWA empowered victims of sex-based crimes by making private acts of sex discrimination civilly actionable under the Fourteenth Amendment's section 5 enforcement authority. See id. at 138 (describing VAWA's remedial scheme as based in equality principles of Fourteenth Amendment Enforcement Clause). In criticizing the majority's Fourteenth Amendment holding, Mackinnon noted that the Court did not challenge the congressional finding that violence against women is a major social problem inadequately addressed by state authorities, nor did the Court dispute that gender-motivated violence constituted discrimination under the Fourteenth Amendment. See id. at 164 (stating Supreme Court's silence was notable given recent section 5 case law).

64. See United States v. Morrison, 529 U.S. 598, 619-20 (2000) (discussing Brzonkala's argument that "there is pervasive bias in various state justice systems against victims of gender-motivated violence"); see also VIOLENCE AGAINST WOMEN: LAW AND LITICATION $\$ 6: 24$ (David Frazee et al. eds., 1998) (discussing approach of state justice systems toward victims of gender-motivated crimes). The Court stated that state-sponsored gender discrimination violates the Equal Protection Clause unless the discriminatory conduct passes intermediate scrutiny. See Morrison, 529 U.S. at 620 (stating that gender classification must serve "'important governmental objectives and ... the discriminatory means employed' are 'substantially related to the achievement of those objectives"'). After reciting the standard for intermediate scrutiny, the Court failed to apply it to $\$ 13981$, instead relying on the state action requirement. See $i d$. (discussing need to limit reach of Fourteenth Amendment).

65. Id. at 619-20; see also VIOLence AGAinst WOMEN, supra note 64, at $\$ 1: 49$ (explaining that " $[\mathrm{w}]$ hen women finally turn to the justice system for protection, they are often treated with derision"). 
nient punishments for those who are actually convicted of gender-motivated violence. ${ }^{66}$

The Court then moved from the section 1 violation of the Fourteenth Amendment to the issue of congressional authority to remedy the unequal protection under section 5. Before turning to the details of the Court's section 5 analysis, however, it is important to step back and examine the section 1 violation because its scope has implications for congressional power to fashion appropriate remedial legislation under section 5 .

\section{Unequal Protection}

Violence against women that is motivated by gender animus includes instances of stalking, battery, assault, rape and homicide. In analyzing how states afford women unequal protection against this kind of violence, I will focus on the social and legal practices surrounding rape because the Morrison case is about rape. Despite my focus, much of what I argue regarding states' unequal protection against rape can also be said of other crimes that are similarly motivated by gender animus. Similar analyses could be made of wife abuse and murder, for example, if one examined the marital tort immunity doctrine ${ }^{67}$ and the gendered notions of provocation $^{68}$ and self-defense in the law of homicide. ${ }^{69}$

Christy Brzonkala's experience of rape was typical in many ways. That she was raped itself is not unusual. ${ }^{70}$ The Centers for Disease Control and Prevention's most recent National Violence Against Women Survey of 8000 women indicates that eighteen percent of women have experienced an attempted or completed rape. ${ }^{71}$ The same survey indicates that twenty-

66. Morrison, 529 U.S. at 619-20 (citing H.R. Conf. REP. No. 103-711, at 385-86 (1994); S. Rep. No. 103-138, at 38, 41-55 (1993); S. ReP. No. 102-197, at 33-35, 41, $43-47(1991))$.

67. See generally Reva B. Siegel, "The Rule of Love": Wife Beating as Prerogative and Privacy, 105 YALE L.J. 2117 (1996) (examining chastisement and implications of modern civil rights reform on its demise).

68. See Victoria Nourse, Passion's Progress: Modern Law Reform and the Provocation Defense, 106 YALE L.J. 1331, 1389-1407 (1997) (discussing reform in "crimes of passion" laws).

69. See generally Femicide: The Politics of Women Kulling (Jill Radford \& Diana E.H. Russell eds., 1992) (discussing woman killing).

70. See MacKinnon, supra note 63 , at 143 (describing societal and legal reality informing Congress' decision to enact VAWA). Evidence substantiating the failure of state justice systems to provide women with equal protection from domestic violence and sexual assault was significant:

One in four women in America reports having been raped, with fortyfour percent reporting having been subjected to completed or attempted rape at least once in their lives. Almost one in ten women between the ages of fifteen and forty-four who has had sexual intercourse reports that her first act of sexual intercourse was "not voluntary."

Id. at 141-42.

71. See Patricia Tjaden \& Nancy Thoennes, Prevalence, Incidence, and Consequences of Violence Against Women: Findings from the National Violence Against Women Survey, Res. IN BRIEF (U.S. Dep't of Justice, Nat'I Inst. of Justice, Ctrs. for Disease 
five percent of women have been either raped or physically assaulted by a spouse, cohabiting partner or date. ${ }^{72}$ The study concludes, "given the pervasiveness of rape and physical assault among American women, it is imperative that violence against women be treated as a major criminal justice and public health concern."73

Brzonkala was raped by acquaintances. Like Morrison and Crawford, the vast majority of rapists are not complete strangers to their victims. Friends and acquaintances commit fifty-three percent of all rapes and sexual assaults. ${ }^{74}$ Intimates-that is, husbands, boyfriends, former husbands

Control \& Prevention), Nov. 1998, at 2; see also S. Rep. No. 101-545, at 43 (1990) (citing testimony by Dr. Mary Koss before the Senate Judiciary Committee) ("[One hundred twenty-five thousand] college women can expect to be raped during this-or any-year."). But see Richard J. Gelles, Estimating the Incidence and Prevalence of Violence Against Women: National Data Systems and Sources, 6 VIOLENCE AGAINST WOMEN 784 (2000) (criticizing present self-reporting surveys that provide local and national data on cases of violence against women); but see also Andrew Percy \& Pat Mayhew, Estimating Sexual Victimization in a National Crime Survey: A New Approach, 6 Stud. on Crime \& Crime Prevention 125, 137-40, 145-47 (1997) (analyzing reasons for underreporting and suggesting new methodology to better measure national sexual victimization figures). Researchers have two principal problems in measuring sexual victimization: first, agreeing what it comprises and, second, obtaining reliable measures. Crime surveys are inadequate measures because many victims simply do not report their experiences to police. The wish to avoid trauma of official action notwithstanding, the most common reason for not reporting is that the victims believe their experience did not meet the legal criteria of "crime." Victims often label offensive behavior in crime surveys as "wrong, but not criminal." In many cases, the offensive behavior does rise to the level of criminal, yet the women do not portray their victimization as a punishable crime. This is particularly true when the offender is an acquaintance instead of a stranger. Therefore, the non-equivalence of legal and social definitions also undermines the extent to which women report sexual victimization. Women need to see themselves as victims of rape in order to report the crime. Although the circumstances may legally qualify as rape, social understanding of rape often differs especially in the context of acquaintance rape. See generally Nathan W. Pino \& Robert F. Meier, Gender Differences in Rape Reporting, 40 SEx RoLes 980 (1999) (analyzing reporting differences based on relationship between rapist and victim and on victim gender). See also R. Barry Ruback, Comment on Bachman (1993): The Victim-Offender Relationship Does Affect Victims' Decisions to Report Sexual Assaults, 20 CRIM. JusT. \& BeHAv. 271 (1993) (stating victim-offender relationship is important because it helps both victim and others define whether or not action is rape and whether or not reporting crime to police is worthwhile); Percy \& Mayhew, supra at 125 (stating that police routinely undercount sexual offenses).

72. See Tjaden \& Thoennes, supra note 71, at 2 (stating statistics of assaults by spouses or dates). Additionally, eight percent of women said they had been stalked at some point in their lives. See id. (noting survey results on stalking).

73. Id. at 11.

74. See Ronet Bachman \& Linda Saltzman, Bureau of Justice Statistics, Special Report: Violence Against Women: Estimates from the Redesigned Survey (U.S. Dep't of Justice), Aug. 1995, at 3, 6 (stating that "[f] riends and acquaintances commit approximately half of all rapes and sexual assaults"). Acquaintances are defined as friends or former friends, roommates or boarders, schoolmates, neighbors, coworkers or some other known non-relative. See id. at 6 . Sexual assaults are defined as unwanted sexual contact that may or may not involve force, including grabbing or fondling. See id. at 7 . 
and former boyfriends-commit an additional twenty-six percent of all rapes and sexual assaults. ${ }^{75}$ In total, acquaintances and intimates commit four out of five rapes and sexual assaults. ${ }^{76}$

Morrison and Crawford did not break Brzonkala's bones, beat her up or threaten her with a gun or knife. They did not have to. Pinning her with their arms and legs was sufficient to force her to have sex against her will. Like Brzonkala, the vast majority of rape victims suffer little or no physical injury extrinsic to the rape itself. Only about ten percent of rape victims suffer extrinsic physical injury. ${ }^{77}$ The major injury most rape victims suffer is psychological.

After being raped, Brzonkala dropped out of school, suffered from depression and attempted suicide. Like Brzonkala, the vast majority of rape victims suffer serious psychological harm from the experience. ${ }^{78}$ Contrary to popular opinion, acquaintance rape victims suffer more psychological damage than do stranger rape victims because self-blame is higher when a woman is raped by an acquaintance. ${ }^{79}$ As one study put it, “[w]omen raped by men they knew attribute more blame for the rape to themselves, see themselves in a less positive light, and tend to have higher levels of psychological distress." 80 Self-blame is correlated with fear, anxi-

75. See id. at 3,6 (giving statistics for rapes and sexual assaults by intimates). Acquaintances and relatives commit thirty-two percent of all homicides committed on women. See id. at 4 . Intimates commit an additional twenty-eight percent of them. See id.

76. See id. at 1, 6 (noting overwhelming percentage of sexual assaults and rapes committed on women by acquaintances and intimates).

77. See Susan B. Sorenson \& Judith M. Siegel, Gender, Ethnicity, and Sexual Assault: Findings from a Los Angeles Study, 48 J. Soc. Issues 93, 97 (1992) (stating low percentage of women physically injured in addition to assault). Therefore, ninety percent usually have little corroborative evidence of the assault in the form of physical harm to their bodies. See id.

78. See C. Lee Wise (pseudonym), Reflections of a Rape Survivor, 27 Women's STud. Q. 162, 163 (1999) (observing uncomfortable social and personal perceptions surrounding sexual crimes that create sense of shame and complicity in victims). Sexual crimes are uniquely traumatic to victims because they instill feelings of collusion, shame and guilt.

79. See Bonnie L. Katz \& Martha R. Burt, Self Blame in Recovery from Rape, in Rape \& Sexual Assault II 162 (Ann Wolbert Burgess ed., 1988) (describing differences in reported self-blame from women raped by strangers and non-strangers).

80. Bonnie L. Katz, The Psychological Impact of Stranger Versus Nonstranger Rape on Victims' Recovery, in Acquaintance Rape: The Hidden Crime 267 (Andrea Parrot \& Laurie Bechhofer eds., 1991). The study also said, "Women raped by strangers also appear to feel recovered sooner than women raped by nonstrangers." Id. Selfblame decreases the speed with which a woman recovers from rape. See Katz \& Burt, supra note 79, at 151 (noting decrease in recovery); see also Julia Schwendinger \& Herman Schwendinger, Rape Victims and the False Sense of Guilt, 15 CRIME \& Soc. Jusr. 4, 4-5 (1980) (examining difficulty in recovery for women with selfblame about rape); David Valentiner et al., Coping Strategies and Posttraumatic Stress Disorder in Female Victims of Sexual and Nonsexual Assault, $105 \mathrm{~J}$. ABNORMAL Psychol. 455, 458 (1996) (explaining that coping through self-blame impedes recovery).

Self-blame has severe psychological and somatic consequences. Self-blame decreases the chance that a woman victimized by rape or attempted rape will tell 
ety and depression, ${ }^{81}$ as well as posttraumatic stress disorder. ${ }^{82}$ This negative symptomalogy can have dire consequences: "The more women blamed themselves for the rape, the more suicidal they had been since the rape, the greater the likelihood that they had been psychiatrically hospitalized, and the lower their self-esteem." 83 In total, nearly one-third of rape victims develop posttraumatic stress disorder, and thirteen percent of rape victims attempt suicide. ${ }^{84}$ Brzonkala's depression and attempted suicide, then, were not unique.

The institutional response to Brzonkala's complaint also was not unique. Brzonkala received no legal or quasi-legal vindication against her rapists. She lodged a complaint under Virginia Tech's Sexual Assault Policy. Two university hearings ended with no conviction for Crawford and a conviction of "using abusive language" for Morrison. The punishment imposed on Morrison was a one-hour educational session. ${ }^{85}$ Like Brzonkala,

someone about the attack, report the rape to the police or obtain necessary psychological support. See Robin Warshaw, I Never Called It Rape 56 (Libbu Kessman ed., 1988) (describing lack of self-help by women with greater amounts of self-blame). When women do not obtain psychological support, they do not hear professional counselors tell them they are not to blame. See Katz \& Burt, supra note 79 , at 165 (reporting that guilt hampers quick recovery and that sixty-five percent of women said that most helpful thing rape crisis counselor said was "you are not to blame").

81. See Katz \& Burt, supra note 79, at 166 (stating that "higher levels of initial self-blame were significantly associated with the presence of more negative symptomalogy such as fear, anxiety, and depression").

82. See Valentiner et al., supra note 80 , at $457-58$ (describing correlation of self-blame with symptoms of posttraumatic stress disorder).

83. See Katz \& Burt, supra note 79, at 151, 162-63 ("The more women felt that they had blamed themselves for the rape, the higher their current levels of psychological distress as measured by negative symptomalogy . . . . Higher levels of selfblame were also associated with more hours of counseling since the rape ... and with the length of time women felt it took (or would take) for them to be 'recovered.") (statistics omitted).

84. See Nat'l Victim Ctr., Rape-Related Post-traumatic Stress Disorder 2 (1992) (discussing incidence of posttraumatic stress disorder in rape victims). Rape victims are 4.1 times more likely than non-crime victims to contemplate suicide. See id.

85. See Miller, supra note 49 , at C1 (relating further misadventures of Morrison and Crawford); see also Lisa K. Garcia, Players Charged with Rape; 2 Members of Va. Tech's Football Team Are Arrested, Roanoke. Times \& World News, Dec. 17, 1996, at Al (noting charge). State police and university officials cleared Morrison and Crawford of criminal liability. Michael Hemphill, Court Hears Brzonkala, Supreme Court Considers Constitutionality of Violence Against Women Act, ROANOKE Times \& World News, Jan. 12, 2000, at A1. Subsequently, however, Morrison was charged with public intoxication, petty larceny, destruction of property and possession of a fake license. See Miller, supra note 49, at C1 (discussing charges that resulted in Morrison being kicked off Hokies' Sugar Bowl Travel Roster). Crawford was charged with defrauding an innkeeper and felony hit and run with injury. See Randy King, Georgia Stories, Rumors Still Dog Hokies' Beamer, Ronnoke Times \& World News, Dec. 12, 1995, at B1 (describing charges against Crawford). A month after being indicted in connection with unrelated assault and abduction allegations, Crawford faced another charge of rape and attempted sodomy after a woman told police she was gang raped by Crawford and another man. See Lisa K. 
the vast majority of rape victims never get to witness their rapists convicted of any serious crime or sentenced to serious punishment. ${ }^{86}$

States historically have denied women equal protection of the law in response to rape, and continue to do so. Traditional common law rules for rape complaints evinced obvious gender bias. Over the past few decades, these rules have changed, but the biased imperatives behind them continue to direct the discretionary decisions of state actors. First, police disproportionately code rapes as "unfounded" or place them in non-criminal codes where they receive little to no investigation. ${ }^{87}$ Also, police disproportionately discourage women who have been raped from proceeding with their complaints. ${ }^{88}$ Furthermore, prosecutors disproportionately dismiss rape complaints. ${ }^{89}$ A state action analysis of violence against women must comprehend not just the formal law but the discretionary decisions of state actors. Through these decisions, state actors deny women who are raped the equal protection of the criminal law.

\section{A. Formal Rape Law Has Historically Been Unequal}

Historically, rape law raised unique procedural hurdles for rape victims that victims of other crimes did not have to surmount. Derived from English common law and applicable in most jurisdictions until the mid to late $1970 \mathrm{~s}$, these formal rules embodied clear presumptions against women who complained of having been raped. ${ }^{90}$ These rules included absolute exemptions from criminal liability for men who raped their wives. ${ }^{91}$ They included requirements that the victim establish that she resisted her attacker to the utmost, freshly complained of having been raped and corroborated her testimony with other evidence. ${ }^{92}$ They included biased suppositions about victims who had previously engaged in sexual intercourse outside of marriage. ${ }^{93}$ Finally, they included special cautionary instruc-

Garcia, 2 Hokies Face Sex Charges, Grand Jury Indicts Former Tech Football Players on Rape, Attempted Sodomy Counts, Roanoke Times \& Worlo News, Apr. 24, 1997, at C1 (reporting rape and attempted sodomy charges against Crawford).

86. See generally Michelle Anderson, Reviving Resistance in Rape Law, 1998 U. ILL. L. REV. 953.

87. For a discussion of "unfounding", see infra notes 116-36 and accompanying text.

88. For a discussion of police discouragement, see infra notes $137-45$ and accompanying text.

89. For a discussion of disproportionate prosecutorial dismissal of rape claims, see infra notes $146-61$ and accompanying text.

90. See Susan Estrich, Real Rape 28 (1987) (noting courts have created "set of clear presumptions against the woman who complains of simple rape").

91. For a discussion of the marital rape exemption, see infra notes 95-97 and accompanying text.

92. For a discussion of the requirement that a woman resist her attacker to the utmost, that she promptly complain and that she provide corroborating evidence, see infra notes 98-104, 108-11 and accompanying text.

93. For a discussion of these biased suppositions, see infra notes $105-07$ and accompanying text. 
tions read to the jury to warn them of the fallibility of the testimony of those who allege they have been raped. ${ }^{94}$

When scholars examine the biased presumptions against women embodied in the English common law of rape, many focus on the marital rape exemption. The marital rape exemption denied married women the protection of criminal rape law, simply by virtue of the fact that they were married. ${ }^{95}$ It provided that a man could not be guilty of rape for anything he did to his wife because, as the Model Penal Code still puts it by definition, rape involves "a male who has sexual intercourse with a female, not his wife." 96 Since the 1970s, most states have eroded or abolished entirely the common law marital rape exemption. ${ }^{97}$

The marital rape exemption is the most obvious gender bias in the common law of rape. Other requirements that historically had to be met before a rape conviction could be obtained were also biased. For example, the historical requirement that a rape victim resist her attacker to the utmost to prove non-consent was unique in the criminal law. ${ }^{98}$ Many other crimes have had a consent defense, but none has defined consent in such a way that "no" would not suffice to disprove it. ${ }^{99}$ The resistance requirement mandated that a woman physically resist her attacker to the utmost to prove both that she did not consent and that he had to use force to subdue her. ${ }^{100}$ The resistance requirement has evolved over the course of the last few decades from an utmost resistance requirement to a reasonable resistance requirement in many jurisdictions to the more common situation today, where no formal resistance requirement remains in many rape statutes. ${ }^{101}$

Historically, in a significant minority of jurisdictions, corroboration of the victim's complaint with other evidence also was a requirement before a

94. For a discussion of these cautionary instructions, see infra notes 112-13 and accompanying text.

95. See Robin West, Equality Theory, Marital Rape, and the Promise of the Fourteenth Amendment, 42 FLA. L. Rev. 45, 63-71 (1990) (examining theory and constitutionality of marital rape exception).

96. Model Penal Code $§ 213.1$ (1) (1980).

97. See Lalenya Weintraub Siegel, Note, The Marital Rape Exemption: Evolution To Extinction, 43 Clev. St. L. Rev. 351, 364-69 (1995) (describing states, such as New York and Oregon, that have completely abolished marital rape exception and other states that have moved towards abolition); see also Rebecca Ryan, The Sex Right: A Legal History of the Marital Rape Exemption, 20 L. \& SoC. INQUIRY 941 (1995) (discussing modern trend toward abolition of exception).

98. See Estrich, supra note 90, at 29 (explaining that crime of rape is unique because definition of non-consent includes element of physical resistance).

99. See id. at 40 ("The requirement that the victim of simple rape do more than say no was virtually without precedent in the criminal law.").

100. See Anderson, supra note 86, at 953 (describing resistance requirement).

101. See id. at 957 (discussing evolution of resistance requirement). 
rape conviction could be obtained. ${ }^{102}$ The extent of corroboration depended on the plausibility of the complaint itself. ${ }^{103}$ Cases involving stranger rapes did not have to be corroborated as much as cases involving acquaintance rapes. ${ }^{104}$

Additionally, the law historically insisted that rape victims be sexually virtuous in order to receive vindication for the sexual transgressions against them. In Biblical times, the crime of rape was limited to the rape of virgins. ${ }^{105}$ The rape of a virgin was not conceptualized as a transgression against a female's sexual autonomy; rather, it was the theft of her chastity, which was a property transgression against her father or future husband. Although a formal virginity requirement waned as English law recognized that women and girls who were not virgins could also be raped, the victim's sexual chastity remained predominant in courts' evaluation of the crime. ${ }^{106}$ The rape of a non-virgin, for example, was not as serious a crime as was the rape of a virgin and was not punished as severely. Even when statutes in both England and the United States made no formal distinctions between virgins and non-virgins, the centrality of the victim's chastity endured. A victim's lack of sexual chastity was considered relevant evidence on the issue of both consent and the victim's credibility as a witness, that is, her propensity to tell the truth. ${ }^{107} \mathrm{~A}$ lack of chastity on the part of the victim suggested both that she had a propensity to consent to sexual intercourse and that she had a propensity to lie.

Historically, the common law of rape also required a prompt complaint before a rape case could be prosecuted. This special rule evolved from the doctrine of "hue and cry," which was a legal expectation that

102. See Estrich, supra note 90 , at 43 (noting that corroboration of rape victim's testimony to support conviction continues to be critical factor in disposition of rape cases today).

103. See id. at 44 (explaining that "[t]he plausibility of the victim's story was determinative").

104. See id. at 42-45 (describing corroboration differences).

105. See Deuteronomy 22:23-27 (reciting distinction). The text of Deuteronomy makes a distinction between the rape of a betrothed virgin and the rape of an unbetrothed virgin. If a man found a betrothed virgin and "the man force her and lie with her" and she cried out against the violation, he was to be punished by being stoned to death. See id. However, "if a man finds a damsel that is a virgin, which is not betrothed, and lay hold on her and lie with her," he had to marry her "because he hath humbled her" and he had to pay her father fifty shekels of silver, which was the bride price. Deuteronomy 22:28-29. The bride price compensated the father for the loss of his daughter's virginity. The only "punishment" for the rape of an un-betrothed virgin (besides paying the usual bride price) was that the man "may not put her away all his days," meaning that he could never divorce her. Deuteronomy 22:29. The punishment of seduction of a "maid that is not betrothed" is also marriage and paying money to the father. Exodus 22:16-17.

106. See Estrich, supra note 90 , at 50-51 (discussing prevalence of chastity requirement).

107. See id. at 47 (noting relevance of victim's chastity). 
victims of rape would cry out immediately after being violated. ${ }^{108}$ The prompt complaint requirement occasionally barred complaints made even one day after the event. ${ }^{109}$ In this country, the prompt complaint rule emerged in some jurisdictions as a short statute of limitations on the filing of rape complaints. ${ }^{110}$ In other jurisdictions, it emerged as a presumption that, without a prompt complaint, a report of rape was false. ${ }^{111}$

Since the nineteenth century, special cautionary instructions to juries in rape cases provide the final example of the common law's distrust of women who complained of being raped. ${ }^{112}$ These instructions directed the jury to evaluate the testimony of a woman who complained of being raped with extra caution. In their usual prescription, the jury was directed to "evaluate the testimony of a victim or complaining witness with special care in view of the emotional involvement of the witness and the difficulty of determining the truth with respect to alleged sexual activities carried out in private." 113 These instructions implied that women are untrustworthy as witnesses and that the jury should not convict a defendant on the basis of their testimony alone.

Most of these biased requirements in rape law-the marital rape exemption, the requirements of resistance, sexual virtue, corroboration, prompt complaint and cautionary instructions regarding a rape complainant's testimony-have been modified or abolished in the law. It may be easy, therefore, to dismiss them as historical wrongs. Such a dismissal would be unwise. Today, the biased traditional requirements are operational in law through more informal channels. They direct the discretionary decisions of police and prosecutors.

\section{B. Police Discretion Over Rape Complaints Is Exercised Unequally}

The criminal justice system is built upon the discretionary decisions of state actors who process criminal complaints. ${ }^{114}$ As cases progress through the system from police to prosecutors to the courts, demands for

108. See Kathryn M. Stanchi, The Paradox of the Fresh Complaint Rule, 37 B.C. L. REv. 441, 446-48 (1996) (describing "hue and cry" rationale); see also Michael H. Graham, The Cry of Rape: The Prompt Complaint Doctrine and the Federal Rules of Evidence, 19 WillameTte L. REv. 489, 491-500 (1983) (reviewing theories that undergird common law prompt complaint rule).

109. See Stanchi, supra note 108, at 451-52 (discussing traditional "strict immediacy requirement" that applied to prompt complaint rule).

110. See id. at $452-53$ (explaining versions of prompt complaint rule in U.S.).

111. See id. at 446 (noting application of rule in some jurisdictions as presumption).

112. See Estrich, supra note 90 , at 54 (illustrating problems caused by cautionary instruction).

113. Id. (emphasis omitted) (citing Model Penal Code and Commentaries $\S 213.6(5)$, at 412$)$.

114. See Joint Anti-Fascist Comm. v. McGrath, 341 U.S. 123, 179 (1951) (Douglas, J., concurring). "It is not without significance, that most provisions of the Bill of Rights are procedural. It is procedure that spells much of the difference between rule by law and rule by whim or caprice. Steadfast adherence to strict 
economy dictate that officials process only select cases. Consequently, a broad area of discretion enables officials to decide which suspects to prosecute and on what charges. Normative values and personal bias inform police and prosecutorial judgments regarding relevant evidence, appropriate procedure and, ultimately, the merits of the complaint. Thus, access to justice for rape victims is often governed not so much by statute but by police and prosecutorial discretion.

The selection process begins when police decide whether a report is valid, whether a reported offense is a crime, whether to investigate the reported crime and whether to arrest a suspect. ${ }^{115}$ Within the context of those discretionary decisions, women have been and continue to be denied equal protection of the law when subjected to criminal violence motivated by gender. The denial of equal protection occurs because police exercise their discretion when dealing with rape complaints in an unfair and unequal manner. This unequal treatment is evidenced by two institutionalized police practices that undermine the process by which rape victims seek protection and justice. First, police disproportionately categorize rape complaints as "unfounded" or log them under non-criminal codes. Second, police disproportionately discourage rape victims from proceeding with their complaints.

\section{Unequal Categorization of Rape Complaints}

Police deny equal protection to rape victims by disproportionately mis-categorizing legitimate rape complaints in two ways. First, police can decide that the victim is fabricating the complaint and deem the complaint "unfounded." 116 Second, police can decide that what happened to the complainant did not constitute a crime and assign the complaint a non-criminal code. ${ }^{117}$ In both instances, police terminate their official obligation to investigate rape allegations further and often deny legitimate victims full redress through the criminal law. ${ }^{18}$ At this early stage of investigation, police disproportionately categorize rape allegations in a manner that denies the occurrence of any criminal wrongdoing. ${ }^{119}$ For

procedural safeguards is our main assurance that there will be equal justice under the law." Id.

115. See Arthur Rosett \& Donald R. Cressey, Justice by Consent 4 (1976) (noting discretionary and selective nature of American criminal justice system). In practice, most official decisions are not governed by a strict rule of law.

116. See Mark Fazlollah, Philadelphia's Hidden Rapes, at http:// www.jrsainfo.org/events/conference/2000-conference/presentations/ mark_fazlollah.html (last visited Nov. 3, 2000) (offering statistics on cases police consider "unfounded").

117. See id. (discussing categorization of victims' reports by police).

118. See Wayne A. Kerstetter, Gateway to Justice: Police and Prosecutorial Response to Sexual Assaults Against Women, 81 J. Crim. L. \& Criminology 267, 268 (1990) (discussing effects of police decision-making with respect to rape victims).

119. See Fazlollah, Philadelphia's Hidden Rapes, supra note 116 (noting police's faulty categorization of rape allegations). An "unfounded" case means that the police believe the complainant lied; non-criminal codes, such as "information only 
example, Philadelphia police have acknowledged that the department's rape squad wrongly shelved approximately 400 cases a year using a noncriminal code as a dumping ground for those cases that the police found difficult. ${ }^{120}$ These cases were not isolated events; the practice of miscoding rapes is endemic. ${ }^{121}$

The labels differ among police departments across the country, but the process is similar. By unfounding and downgrading crimes involving violence against women, police departments neglect to investigate hundreds, perhaps thousands, of legitimate rape complaints every year. ${ }^{122}$ As a result, rape complaints fall into statistical blackholes, cities underreport their rape rates and police departments deny women equal protection and justice. For example, in the past decade, the Philadelphia Police Department decided that a fairly large percentage of reported sexual assaults were unworthy of further investigation. ${ }^{123}$ During that time, the rate for "unfounded" rape complaints reached eighteen percent, and the rate for

report" and code "2701," generally suggest that the alleged events, whether true or not, did not constitute criminal conduct. See id. (defining "unfounded").

120. See Craig R. McCoy \& Mark Fazlollah, DNA Backs a Rape Story Police Ignored, PhILA. InQuIRER, Oct. 3, 2000, at B1 (illustrating typical procedure that leads to "unfounding" of legitimate rape allegations). Immediately after being abducted and raped, a seven year-old Philadelphia girl was found wandering alone in a North Philadelphia neighborhood. See Mark Fazlollah, Police May Ignore Rape Complaints to Boost Image (June 15, 2000), available at http://www.womensnews.org (discussing events surrounding girl's rape). A responding patrol officer questioned the girl, wrote up the report as a case of a "lost child" and made no mention of the child's rape allegations. See id. (same). Subsequent pressure from the girl's family lead the department's sex-crime unit to proceed with a cursory investigation. Melody Madison was beaten and raped in a deserted Philadelphia playground. See id. (same). The city's sex-crime unit said it could not contact Madison after a detective initially interviewed her in August 1995 at the hospital were she was treated for a blow that knocked four of her teeth out. See id. (same). Without a second interview, police insisted they could not verify if a crime took place and therefore classified the allegation as code "2701." See id. (same).

121. See Fazlollah, Philadelphia's Hidden Rapes, supra note 116 (highlighting propensity to unfound and underreport rape rates in other metropolitan areas). "The practices we found in Philadelphia appear in cities large and small." Id. The Phoenix rape squad shelves difficult rape cases with a code called "information only report." See id. (noting rape case procedure of Phoenix rape squad). According to a former Phoenix sex crimes supervisor, approximately one third of the city's sexual assault complaints were classified as "information only." See id. (same). Milwaukee has repeatedly reported more than forty percent of rape complaints were "unfounded." See id. (discussing Milwaukee rape squad procedure).

122. See id. (noting effects of police's unfounding and downgrading of crimes). After Philadelphia Inquirer reporter Mark Fazlollah put a spotlight on the habitual unfounding of rape allegations by the Philadelphia rape squad, the city police department reopened the 2,000 cases buried by code "2701" during the past five years. See id. (noting reaction of police department after press initiated scrutiny). To date, police have already made forty-six arrests from cases dating to 1995. See id.

123. See id. (discussing decisions of Philadelphia police with respect to sexual assaults). 
assigning non-criminal codes to sexual assault complaints reached thirty percent. $^{124}$

Other cities have experienced similar problems. In 1989, for instance, the Oakland Police Department coded twenty-five percent of reported rapes as "unfounded." 125 More common than even this high "unfounded" rate, cases would be left in pending files on police officers' desks without proper investigation. ${ }^{126}$ Mark Melton, a deputy district attorney in Oakland, explained that so many complaints were ignored because "[police] tend to see a black woman smoking crack as a woman who is willing to give herself up for dope. They consider that tantamount to consent if you are smoking [crack]. Credibility is everything."127 After a three-month investigation by the San Francisco Examiner, the Oakland Police Department was forced to re-open and investigate more than 200 sexual assaults it had miscoded as "unfounded."128

Even more recently, Milwaukee has reported that more than forty percent of rape complaints made to its police department were "unfounded."129 Virginia Beach currently reports that about fifty percent of all rape complaints made to its police department are unfounded. ${ }^{130} \mathrm{~A}$ Chicago Police Department audit of 2386 random "unfounded" complaints concluded that " $\mathrm{t}]$ here exists among detectives an insensitivity to the victim's plight." ${ }^{31}$ When the victim violated sex role norms, police were much more likely to unfound the complaint and choose not to arrest. ${ }^{132}$ Additionally, the audit found that a victim's failure to complain promptly and a lack of corroborative evidence greatly impacted the police department's decision to unfound the case and to arrest a suspect. ${ }^{133}$

124. See id. (offering statistics for unfounded "rape" cases).

125. See Michael J. Ybarra, In Search of Justice: Oakland Woman Says She was Raped and Pushes the System to Follow Up, L.A. TIMEs, Apr. 11, 1991, at E1 (noting treatment of reported rapes by Oakland police).

126. See Jane Gross, To Some Rape Victims, Justice Is Beyond Reach, N.Y. Times, Oct. 12, 1990, at A14 (discussing neglect of pending files by Oakland police).

127. Ybarra, supra note 125 , at E1.

128. See Oakland Police Say They Ignored Sex Assault Cases, Cirl. Trib., Feb. 4, 1991 , at 4 (stating that Oakland police responded to press inquiry by re-examining cases).

129. See Fazlollah, Philadelphia's Hidden Rapes, supra note 116 (offering statistics on handling of rape cases by Milwaukee police).

130. See id. at 2 (discussing handling of rape case in Virginia Beach). By the same token, departments that report extraordinarily low rates of "unfounding" may be fiddling with numbers. Houston reports only one half of one percent of all rapes reported are "unfounded." See Gross, supra note 126 (noting low percentage of "unfounded" rapes in Houston police department). Houston police are not required to write a formal police report if they do not think a rape complaint constitutes a real crime. See id. (discussing requirements).

131. Kerstetter, supra note 118 , at 281.

132. See id. (discussing likelihood of police's unfounding of complaints).

133. See id. (noting factors that influence police's decision to unfound cases). 
Why unfound or ignore so many rape complaints? There are stories of police incompetence, bias and insensitivity to the plight of victims. ${ }^{134}$ More importantly, perhaps, police continue to weigh factors in their discretionary decisions that the law no longer formally requires: the degree of resistance, whether a woman violated sex role norms, the promptness of her complaint and the relationship between the victim and the offender. ${ }^{135}$ Regardless of cause, the effect is deleterious: many women who report rape do not receive equal protection. ${ }^{136}$

\section{Unequal Pressure on Victims to Withdraw Rape Complaints}

Police also deny women equal protection of the law by disproportionately pressuring those who report being raped to withdraw their complaints. One major study indicates that a victim's decision to report having been raped to the police is influenced by social expectations about whether or not to report. ${ }^{137}$ Social expectations, including those of the police, also influence a victim's decision to withdraw her complaint. ${ }^{138}$ The victim's decision to withdraw a complaint after it is lodged with the police "is more complex than simply a statement of victim volition."139 The police detective's "perceptions of the likely success of prosecution" of a victim's claim bear on the victim's decision to proceed. ${ }^{140}$ The disproportionate impact police officers have on a victim once she complains of having been raped is an ordinarily unexamined aspect of powerful police influence. ${ }^{141}$

134. See Diana E.H. Russell, The Politics of Rape: The Victim's Perspec TIVE 181, 202, 224 (1984).

135. See Kerstetter, supra note 118, at 310-11 (offering factors police use to make determinations of whether to unfound cases).

136. See Russelt, supra note 134, at 241 .

137. See Greenberg \& Ruback, supra note 12, at 176 (examining role of social influence on victims decision to report victimization to police). Rape victims' predominant emotional reaction to their victimization is fear demonstrated by their immediate need to obtain protection and emotional support. Consequently, social influence is an important determinant in a rape victim's decision to report their victimization to police. See id. at 177 (reporting high percentages of victims consult with others before reporting). Moreover, the study suggests that, after reporting, continued supportive behavior is critical to the victim's decision to ultimately pursue the case through the criminal justice system. See id. at 176.

138. See id. (stating that positive reaction to victim and absence of pressure to drop case are closely correlated with likelihood of case proceeding through system).

139. Kerstetter, supra note 118, at 307.

140. See id. at 301 (stating that victims often experience apprehension when deciding whether to prosecute).

141. See id. at 309 (noting that police use complainant's apprehension as leverage against complainant). The study concluded that a scientific analysis of "complainant willingness to prosecute may, in fact, be disclosing the circumstances under which detectives tend to be inclined or disinclined to pursue a complaint." Id. 
Another study that analyzed police influence revealed that a victim's willingness to prosecute her claim after she has reported the rape to the police "[represents] a major point of [police] discretion, partly because the decision is superficially not an official decision." 142 As the study explained, "the detective does not have to create the elements by which to manipulate the victim's decision; all that is required is a selective presentation of the reality. . . that confronts her."143 For example, police may persuade a victim to withdraw the complaint by emphasizing the wellknown obstacles that she will face if she does proceed, including a grueling cross-examination by the defense attorney and the limited likelihood of success at trial. The complicated set of reasons considered by a victim when choosing whether to proceed "provides the detective the possibility for manipulation." 144 The study concluded, "[t] hese interacting dimensions, namely low visibility, credible risks for the citizen, situational ambiguity, low credibility of potential complainant, and self-interest of an official, provide a model for the appearance and dynamics of the abuse of discretion in official decision-making." 145

\section{Prosecutorial Discretion Over Rape Complaints Is Exercised Unequally}

Independent of the work of police, prosecutors also deny women equal protection of the law by dismissing rape cases disproportionately. If a rape victim reports having been raped to the police, and if police found the complaint and make an arrest, then police turn the case over to the district attorney's office for prosecution. At that point, prosecutors act as "gatekeepers" in deciding which of these rape cases will be prosecuted. ${ }^{146}$ Unfortunately, prosecutors keep a disproportionate number of rape victims waiting at the gate. The Senate Judiciary Committee found that prosecutors are twice as likely to dismiss a rape case as to dismiss a murder case, and about forty percent more likely to dismiss a rape case than to dismiss a robbery case. ${ }^{147}$

Of those rape cases police deliver to the district attorney's office for prosecution that fail to result in a conviction, eighty-nine percent are the result of prosecutorial dismissals. ${ }^{148}$ One former chief of the sex crimes unit in New York City, Alice Vachss, recounted, "[a]mong those rapists

142. Id. at 303 .

143. Id. at 304 .

144. Id.

145. Id.; see also VIOl.ence Acainst Women, supra note 64 , at $\$ 1: 49$ (noting empirical evidence of justice system's selectivity and insensitivity to complaints of gender-motivated crime).

146. See generally Lisa Frohmann, Discrediting Victims' Allegations of Sexual Assault: Prosecutorial Accounts of Case Rejections, 38 Soc. Probs. 213 (1991).

147. See S. Rep. No. 103-138, at 42 (1993).

148. See Alice Vachss, Rape and Denial, New Republic, Nov. 22, 1993, at 14 (noting percentage of cases dismissed by prosecutors after failing to result in convictions). 
actually arrested, few are vigorously prosecuted." 149 She contended, the most "dangerous" aspect of the nearly unfettered prosecutorial discretion to cherry-pick cases for trial is that this discretion. "is exercised in the dark, often by minimally trained law graduates, with few systems in place to protect against bias or stupidity." 150 Why then do prosecutors reject so many cases? "Prejudice is one answer," Vachss said. ${ }^{151}$ "Many victims fail to meet (undisclosed, unacknowledged and always denied) law enforcement standards for behavior, background or ethnicity." 152

Research corroborates Vachss' contention. One seventeen-month study in 1991 of two district attorneys' offices in different cities involved the observation of more than 300 case screenings where district attorneys decided whether cases were accepted or rejected for prosecution. The study revealed that discretion was often exercised against women who were homeless, prostituted, addicted or involved in other criminal activity. ${ }^{153}$ The study also revealed that "prosecutors rely on assumptions about relationships, gender, and sexuality" in deciding whether to seek an indictment in rape cases, ${ }^{154}$ and that the negative implications of this policy were "particularly acute for acquaintance rape" victims. ${ }^{155}$

Prosecutors discredited victims' allegations of sexual assault to justify rejecting cases. ${ }^{156}$ Prosecutors compared the facts of cases to what they believed would be the facts of "typical" rapes, and used such comparisons to reject many complaints for prosecution. For example, one district attorney justified his rejection of an extended kidnapping in which the victim was raped vaginally because, "my experience has been that when a rapist has a victim cornered for a long time, they engage in multiple acts and different types of sexual acts." 157 Another district attorney justified his rejection of an assault that included three anal rapes because, "[i]t seems to me he should be doing more than [anal rape] by the third time." 158

The traditional common law requirements of rape also came into play more during this process of rejecting claims for prosecution. The study recounted one district attorney who rejected a complaint because the victim failed to report promptly. The district attorney said, "[s] he didn't call the police until four hours later. That isn't consistent with someone who

149. Id. Vachss continues, "I saw my share of rapists freed by bad laws. More often, however, I saw rapists freed by prosecutors unwilling even to step into the ring." Id.

150. Id.

151. Id.

152. $I d$.

153. See Frohmann, supra note 146, at 222.

154. Id. at 224.

155. Id.

156. See id. at 215.

157. Id. at 217.

158. Id. 
has been raped." 159 District attorneys rejected other cases for lack of corroboration; one district attorney declared that she would never "file a oneon-one case," which is a case without corroborative evidence beyond the testimony of the victim herself. ${ }^{160}$ Therefore, this study found that prosecutors exercised their discretion to dismiss rape complaints for failure to report promptly, lack of corroboration and victim deviation from the norms of appropriate female behavior. The historical impediments written into rape law are thus related to today's disproportionate exercise of prosecutorial discretion. Alice Vachss put it this way: “[d]espite the advent of improved legislation, the underprosecution of sex crimes continues: no longer tactically impossible, underprosecution has become a law enforcement choice." 161

A study of the Uniform Crime Reports and National Crime Victimization Surveys from 1973 to 1990 provides some statistical support for Vachss' position. The study revealed that statutory rape law reforms have "not had a very substantial effect" on "actual practices in the criminal justice system." 162 Despite rape law reforms, for example, there continued to be a large "discount" for those who rape acquaintances. ${ }^{163}$ The study noted, "[a]lthough attitudes about rape and rape victimization may have become more enlightened in the past two decades, there is little evidence to suggest that these attitudes have been translated into significant performance changes in the criminal justice system."164 Selective prosecution of gender-motivated crimes also does not stop with police and prosecutor selectivity. Judges also exercise discretion, and can trivialize women's complaints of abuse and impose de minimis sentences on men who abuse their partners. ${ }^{165}$ Despite the significant statutory reforms over the past few decades, not much has changed for many women who report having been raped to the police. ${ }^{166}$ The biased common law requirements of rape continue to infect the process.

Police do not treat crimes against women equally to how they treat other crimes. Rape is not taken as seriously and rape victims are dispro-

159. Id. at 219.

160. Id. at 220 .

161. Id.

162. Ronet Bachman \& Raymond Paternoster, A Comtemporary Look at the Effects of Rape Law Reform: How Far Have We Really Come?, 84 J. CRIM. L. \& CRIMINoL OGY 554, 573 (1993).

163. See id. at 574 (stressing continued "acquaintance discount" among rapists of acquaintances).

164. Id.

165. See Violence Against Women, supra note 64, at \$ 1:49 (noting empirical evidence of justice system's insensitivity to complaints of gender-motivated crime).

166. Studies in thirty states documented widespread bias by not only prosecutors but judges as well. See Editorial, Real Crime, Real Punishment, USA TODAY, Mar. 1, 1994, at 10A (discussing findings of country-wide bias study). For instance, "the Colorado Supreme Court Task Force on Gender Bias in the Courts indicated that $41 \%$ of judges believed that juries give sexual assault victims less credibility than other crime victims." S. REP. No. 102-97, at 47 (1991). 
portionately discouraged from utilizing state resources to vindicate their rights. State indifference, failure to provide adequate law enforcement resources and the lack of will to enforce rape laws encourage rape to proceed unhindered. This is the state action that denies women the equal protection of the laws.

After four years of hearings on the matter beginning in 1990, Congress made findings regarding women and criminal law enforcement. In a series of congressional hearings, attorneys, victim advocates, health care practitioners, judges, victims themselves and others testified to a chronic problem of under-enforcement of the criminal law in areas affecting women. ${ }^{167}$ Congress heard extensive testimony that women who had been sexually victimized were considered at fault, unharmed or not credible. ${ }^{168}$ Based on these hearings, Congress determined that state laws and criminal justice systems, deeply infected with gender bias, had failed to investigate, prosecute or otherwise remedy many crimes of rape and other forms of violence against women. ${ }^{169}$ Congress concluded that the "overwhelming enforcement failure fuels gender-based violence and allows it to continue unchecked."170

\section{Women Do Not Report the Violence They Suffer}

States are such chronic bad actors in the area of violence against women that most women who suffer rape have no faith that the state will take their claims of victimization seriously. As a result, the vast majority of women do not report to state authorities when they suffer sexual violence. ${ }^{171}$

167. See S. REP. No. 102-97, at 47 (offering congressional testimony demonstrating that women do not receive equal treatment under criminal laws).

168. See id. (noting generalized perceptions of criminal justice system regarding raped women).

169. See Pamela Coukos, Deconstructing the Debate Over Gender and Hate Crimes Legislation, 1 GEo. J. Gender \& L. 11, 37 (1999).

170. Id.

171. According to Catherine MacKinnon, the justice system's failure is a product of both the content and the administration of present laws. See MacKinnon, supra note 63 , at 142-43 (criticizing rape law and police administration of rape law). For example, because most rape victims share a degree of acquaintance with their attackers, one can trace the ubiquity of sexual assault to state law conferring on men latitude to force sex on women according to the degree of intimacy men have, or have had, with their victim. See id. at 142 (observing that marital rape exception is most explicit example of state law granting impunity due to relationship between rapist and victim). Furthermore, the routine harassment justice officials subject women to when reporting sexual assault and the pervasive police practice of "unfounding" rape claims make women feel violated by their encounters with the justice system and ultimately discourages reporting all together. See id. at 143 (describing "second rape" phenomenon). Indeed, aware of the fact that the criminal justice system does not prosecute most reported rapes and that most prosecuted rapes do not result in conviction, women do not report most sexual assaults. See id. at 142 (stating that victims reasonably anticipate that authorities will not believe them or will humiliate them). Accordingly, the present body of law has failed to provide equal protection to women and requires a conceptual 
According to the Bureau of Justice Statistics, rape is the violent crime least likely to be reported to the police. ${ }^{172}$ Eighty-four percent of rape victims do not report having been raped to the police. ${ }^{173}$

A woman's judgment about the costs and benefits of legal intervention is shaped by her perceptions of likely institutional reactions. ${ }^{174}$ Women know what has happened to rape victims in the past and what often continues to happen today: embarrassing questions by the police and prosecutors in private and by defense attorneys in public about a victim's sexual history, the implicit argument that the woman assumed the risk of sexual violence by looking or acting "provocatively" and the focus on the woman's failure to employ sufficient resistance against the man she now claims attacked her. ${ }^{175}$

Studies provide support for the notion that this "prejudicial handling by the criminal justice system has increased nonreporting." 176 The decision to report a sexual assault is influenced by prevalent perceptions of police hostility toward sexual assault victims. ${ }^{177}$ Indeed, victims know that reporting will result in secondary victimization from negative treatment by

overhaul. See id. at 138-39 (noting that laws defining rape were drafted by men long before women had right to vote).

172. See Ronet Bachman, Is the Glass Half Empty or Half Full, 22 Crim. Just. \& BEHAv. 81, 94 (1995) (stating that rape is violent crime least likely to be reported to police).

173. See Nat'L Vicism CTr., supra note 1, at 6 (1992).

174. See generally Pino \& Meier, supra note 71 (analyzing underlying causes of failure to report sexual victimization in men and women).

175. See id. at 980 .

176. Alan J. Lizotte, The Uniqueness of Rape: Reporting Assaultive Violence to the Police, 31 Crime \& Deline. 169, 185 (1985). Independent of a host of other accuracy problems with self-reported surveys, one should be cautioned from relying on the results of previous surveys about why crime victims chose not to report their victimization to the police because they did not focus specifically on the extent to which a woman's perception that the criminal justice system will not take her claim seriously is the reason she does not report. The results of some surveys, nevertheless, are suggestive. One study found that sixty percent of rape victims did not report having been raped to the police because of their low expectations regarding the police response. See generally QueEn's Bench Found., RAPE-Prevention and REsisTANCE (1976) (identifying reasons for unreported rapes). Another study found that thirteen percent of rape victims did not report having been raped to the police because the police are inefficient, ineffective or biased. See U.S. Dep'T of Justice, Bureau of Justice Statistics, Highlights from 20 Years of Surveying CRIME Victims 33 (1993). Another study found four percent had no faith that the police could do anything about the matter, twenty-eight percent say it was a private matter. Eleven percent said they had no faith the police would do anything about the matter. Seventeen percent were afraid of reprisals from the offender, believing that the police could not effectively protect them. And forty percent are other. See Ronet Bachman, U.S. Dep't of Justice, Bureau of Justice Statistics, VioLENCE Against Women 11 (1994).

177. See generally Rape Reporting to the Police: Exploring the Social Psychological Impact of Persuasive Campaign on Cognitions, Attitudes, Normative Expectations and Reporting Intentions, 2 INT'L REV. VICTOMOLOGY 277 (1993) (assessing impact of perceived positive behavioral outcomes on victims' decision to report sexual violence). 
police who harp on irrelevant details and confront victims with disbelief and distrust. ${ }^{178}$ Unlike other crime victims, rape victims tend to anticipate how they will be treated and the likely outcome of the case before they decide whether to report the crime to the police. ${ }^{179}$ As a result, rape victims "tend to only report 'dead bang' cases. That is, they tend to report to the police only when the probability of conviction is high. And, of course, they tend not to report when it is low." 180

Christy Brzonkala knew she did not have a "dead bang case." She was raped by two acquaintances who were football players. She did not report the rapes to the police. If one examines the reasons she offered for not reporting, one can see the way the biased common law rape requirements were operational, even in her own mind. According to Brzonkala's complaint, she believed that "criminal prosecution was impossible because she had not preserved any physical evidence of the rape." 181 Her analysis mirrors the common law requirements of prompt complaint and corroboration that no longer formally apply but continue to direct the discretionary decisions of police and prosecutors. In all likelihood, Brzonkala anticipated correctly that Virginia police and prosecutors would not have pursued her case because she was an acquaintance rape victim who had no physical evidence to corroborate her story. She had waited too long to report. These legal rules-corroboration and prompt complaint-also influenced the state grand jury that, two years later, refused to indict Morrison and Crawford on rape charges. ${ }^{182}$

Despite decades of legal reform of the formal law of rape, there has not been a substantial change in the proportion of victims who are willing to report having been raped to the police. ${ }^{183}$ From the 1970 s to the 1990 s, there was only a "slight (approximately 10\%) increase in the pro-

178. See id. at 282. The study also demonstrated that a persuasive communication campaign could stimulate victim reporting by increasing the perceived probability of positive outcomes and in strengthening the perceived normative expectations to report. See id. at 292. To that end, the study showed a video of police officers in initial meetings with victims, treating the victims in a positive manner, not questioning the integrity of the victims, responding to attendant fears and helplessness of victims with empathy and providing clear procedural information to victims. See id. at 286 . The information resulted in a statistically significant positive shift in attitude toward reporting and thereby suggested that underreporting results from negative perceptions and expectations associated with police treatment of victims. See id.

179. See id.

180. Id.

181. Brzonkala v. Va. Polytechnic Inst. \& State Univ., 132 F.3d 949, 954 (4th Cir. 1997), affd, United States v. Morrison, 529 U.S. 598 (2000).

182. See No Action on Hokie Players, N.Y. TiMEs, Apr. 11, 1996, at B6 (stating that grand jury refused to indict Morrison and Crawford on rape charges).

183. See Bachman \& Paternoster, supra note 162, at 573 ("statutory rape law reform has not had a very substantial effect on . . . victim behavior"). Despite better overall education and recent penal reforms, negative social attitudes about sexual crime victims-i.e., that "she asked for it"-continue. Wise, supra note 78 , at 27. 
portion of women who reported being the victim of a rape." 184 Of all the variables that influence the victim's decision to report having been raped to police, the relationship between the offender and the victim appears to be the most important. ${ }^{185}$ Women are less likely to report acquaintance rape situations, and eighty percent of rape victims are acquaintance rape victims. ${ }^{186}$ The historical police response to rape victims, particularly acquaintance rape victims, has created powerful psychological barriers to rape reporting, such that, even as external social factors change, women continue to experience anxiety, embarrassment and self-blame as a result of sexual victimization. ${ }^{187}$

Three related facts, then, are key: 1) historical and continued unequal state action regarding gender violence; 2) women's justifiable pessimism about states' willingness to respond equally to the violence they suffer; and 3) women's consequent reluctance to report gender violence to state actors. In response to the chronic denial of their equal protection rights, women have little to no faith in states to afford them a remedy. The reality of state action, then, extends further than how state actors respond to those (relatively few) women who do report having been raped. States deter women from turning to their authority because the protection they offer is unequal.

This is the scope of the section 1 violation: the vast majority of women have no legal state remedy for suffering rape. They have little hope of legal vindication against their assailants in their state criminal justice systems. They have no way to force states to pursue their legal vindication. These facts have important implications for what Congress may do under section 5 of the Fourteenth Amendment to remedy this section 1 violation.

184. Bachman \& Paternoster, supra note 162 , at 574.

185. See generally Linda S. Williams, The Classic Rape: When Do Victims Report?, 31 Soc. ProBs. 459 (1984) (identifying factors correlated with reporting rapes).

186. "A close relationship usually results in a less violent assault, which in turn means less likelihood of injury and medical treatment." Id. Without corroboration of the crime, the victim is less likely to be believed by state actors.

187. See generally Renee L. Binder, M.D., Why Women Don't Report Sexual Assault, 42 J. ClinICAL PSYCHIATRY 437 (1981) (identifying reasons for not reporting sexual assaults); see also BACHMAN, supra note 176 , at 81 (recognizing need for women to report sexual victimization to increase deterrent effect on would-be rapists). Bachman states:

Because the majority of rape victims from this sample did not ... report their victimization to the police, aggressive attempts should be made to make both the reporting and adjudication process of rape less threatening to victims .... More generally, educational efforts should continue to be directed at aligning societal perceptions regarding rape with contemporary legal statutes that more equitably treat rape like other forms of violent crime. In doing this, the historical stigma attached to being a rape victim may further abate, and public attitudes concerning rape might one day catch up to legal norms. With these efforts made, perhaps the reluctance of victims to report and prosecute cases of rape will continue to be reduced.

BACHMAN, supra note 176 , at 81 . 
Under section 5 of the Fourteenth Amendment, Congress has the power to authorize women to sue their assailants in federal court. Because the criminal justice system deters women from reporting the violence they suffer to state actors, a remedy against these non-state actors is most appropriate.

\section{Morrison's Section 5 Analysis}

In Morrison, the United States Supreme Court concluded that Congress lacked constitutional authority to enact $\$ 13981$ of VAWA under section 5 of the Fourteenth Amendment. The Morrison Court's analysis of section 5 is no model of judicial clarity. It is fair to say, however, that the Court concluded that Congress exceeded its authority under section 5 for three reasons. First, the Fourteenth Amendment applies to state action, not private conduct, and violence against women is private conduct. ${ }^{188}$ Second, $\$ 13981$ fails the congruence and proportionality test for section 5 enactments $^{189}$ as announced by the Court in the recent case of City of Boerne v. Flores. ${ }^{190}$ Finally, $\S 13981$ provides a uniform remedy for violence against women, but congressional findings indicated that the problem of unequal protection of the law did not exist in all or even most of the states. ${ }^{191}$ The Court was wrong on all three counts, as each failed to grapple with the true scope of the section 1 violation and the power granted to Congress by section 5 to remedy that violation.

\section{A. State Action}

The Court began its analysis of the section 5 issue by identifying the "first and foremost" limit on congressional power under section 5-the "time-honored principle" that the Fourteenth Amendment proscribes only state action. ${ }^{192}$ The Court reaffirmed that the Amendment "erects no shield against merely private conduct, however discriminatory or wrongful." 193 The Court concluded that $\S 13981$ was not a constitutional exercise of congressional authority under section 5 because it addressed the

188. See United States v. Morrison, 529 U.S. 598, 621 (2000) (stating that Fourteenth Amendment's applicability is limited to state actions).

189. See id. at $625-26$ (stating that $\$ 13981$ does not meet congruence and proportionality test).

190. 521 U.S. 507 (1997).

191. See Morrison, 529 U.S. at 626 (noting Congress' findings that discrimination against gender-motivated targets is not present in all states).

192. See id. at 621 ("Foremost among these limitations is the time-honored principle that the Fourteenth Amendment, by its very terms, prohibits only state action.").

193. Id.; see also The Civil Rights Cases, 109 U.S. 3, 11 (1883) (declaring unconstitutional public accommodation provision of Civil Rights Act of 1875 because Fourteenth Amendment did not protect against "[i]ndividual invasion of individual rights"); United States v. Harris, 106 U.S. 629, 640 (1883) (invalidating statute because it was directed "exclusively against the action of private persons, without reference to the laws of the State or their administration by her officers"). 
private actions of individuals who committed violence against women, instead of addressing the state action itself. ${ }^{194}$ Because it was not directed at a state or state actor, the Court found that $\$ 13981$ impermissibly targeted private individuals. ${ }^{195}$

In the Civil Rights Cases in 1883, the United States Supreme Court rejected the argument that Congress had the authority under section 5 of the Fourteenth Amendment to protect a person's civil rights from intrusion by private actors. ${ }^{196}$ The Court reasoned that the Fourteenth Amend-

194. See Morrison, 529 U.S. at 626 (stating that $\$ 13981$ was directed at private actors who have committed gender-based crimes and not states or state actors). The Court began by noting that Congress' power under section 5 includes the power to "prohibit conduct which is not itself unconstitutional and [to] intrude into "legislative spheres of autonomy previously reserved to the States." IId. at 619 (quoting Flores, 521 U.S. at 518). Although the grant of enforcement power under section 5 appears broad, the Court has recognized textual and constitutional limits on the amendment. See id.

Brzonkala argued that the state action requirement had been overruled by the Court. See id. at 622. In United States v. Guest, 383 U.S. 745 (1966), two justices expressed the view, in separate concurring opinions, that Congress could prohibit actions by private individuals, even in the absence of state action. See Morrison, 529 U.S. at 622 (summarizing concurring opinions in Guest). Justice Brennan, author of one of the concurring opinions, stated that the Civil Rights Cases were incorrectly decided. See id. at 622-23 (Brennan, J., concurring) (stating that Congress can regulate actions of private individuals) (citing Guest, 383 U.S. at 774). Justice Clark, author of the other concurring opinion, stated that Congress could "punis[h] all conspiracies-with or without state action." Id. at 623 (Clark, J., concurring) (citing Guest, 383 U.S. at 762).

Brzonkala also relied on District of Columbia v. Carter, 409 U.S. 418 (1973), for the proposition that the state action requirement had been overruled. See Morrison, 529 U.S. at 624 (discussing holding in Carter). The Morrison Court rejected Brzonkala's reliance on Guest because the case involved state action; therefore, the statements that Congress could prohibit actions by private individuals were dicta. See id. at 623 (stating that actual state involvement in case "eliminated any need to decide 'the threshold level that state action must attain in order to create rights under the Equal Protection Clause'"). The Morrison Court stated that although Justice Brennan's opinion was "reasoned," Justice Clark's opinion was "naked dicta." See id. (rejecting Brzonkala's argument that Guest eliminated state action requirement). The Court then rejected Brzonkala's reliance on Carter because the opinion contained only a footnote reference to the dicta in Guest. See id. ("This litany is of course entirely dicta, and in any event cannot rise above its source.").

The Morrison Court adhered to the doctrine of stare decisis because the decisions in Harris and the Civil Rights Cases have remained good law for over a century. See id. (describing why Morrison Court refused to consider challenges to Fourteenth Amendment state action requirement).

195. See Momison, 529 U.S. at 626 ("Section 13981 is not aimed at proscribing discrimination by officials which the Fourteenth Amendment might not itself proscribe; it is directed not at any State or state actor, but at individuals who have committed criminal acts motivated by gender bias."). According to the Court, the civil remedy directed at private individuals made $\S 13981$ "unlike any of the $\$ 5$ remedies that we have previously upheld." Id. But see generally Sally Goldfarb, Violence Against Women and the Persistence of Privacy, 61 OHIO ST. L.J. 1 (2000) (criticizing Brzonkala Court's Fourteenth Amendment analysis).

196. See generally Civil Rights Cases, 109 U.S. 3 (holding Constitution did not authorize Congress to regulate conduct of private actors for purpose of protecting against intrusion of individual rights). 
ment protected an individual from an official "abrogation and denial of rights," and not merely the "invasion" of the person's civil rights. ${ }^{197}$ According to the Court, only the state could breech an individual's rights in a way that would implicate the Fourteenth Amendment. ${ }^{198}$ Although scholars and subsequent Supreme Court Justices have challenged the Court's reasoning, ${ }^{199}$ the Civil Rights Cases have not been over-

197. See id. at 11, 17-18 ("It is state action of a particular character that is prohibited. Individual invasion of individual rights is not the subject-matter of the amendment."). The Court stated:

The wrongful act of an individual, unsupported by any such authority, is simply a private wrong, or a crime of that individual; an invasion of the rights of the injured party, it is true, whether they affect his person, his property, or his reputation; but if not sanctioned in some way by the State, or not done under State authority, his rights remain in full force, and may presumably be vindicated by resort to the laws of the State for redress.

Id. at 17.

198. See id. at 18 ("This abrogation and denial of rights, for which the states alone were or could be responsible, was the great seminal and fundamental wrong which was intended to be remedied. And the remedy to be provided must necessarily be predicated upon that wrong. It must assume that in the cases provided for, the evil or wrong actually committed rests upon some State law or State authority for its excuse and perpetration.").

199. See, e.g., Hayward D. Reynolds, Deconstructing State Action: The Politics of State Action, 20 OHı N.U. L. Rev. 847, 854-55 (1994) (arguing for abolishment of state action doctrine). Professor Hayward argues that,

The infamous state action requirement, which was politically crafted by the United States Supreme Court in 1883 in the Civil Rights Cases, must be relegated to the trash heap if the United States of America is even modestly serious about our professed social and constitutional ideals of equality and liberty.

Id. at 847; see also MacKinnon, supra note 63, at 153 (asserting Court was wrong in stating that "all statutes under the Fourteenth Amendment do or must address only state action"). Citing the Klu Klux Klan Act and testimony from the congressional hearings on the Fourteenth Amendment, MacKinnon asserts that, at the time of enactment, Congress intended the Amendment to protect against privately executed deprivations that the State, "by its neglect or want of power" was unable to prevent or properly punish. Id. at 154 (quoting congressional testimony from amendment's hearing). Mackinnon argues that the distinction between public and private as drawn by the Court limited equality rights to the narrowest of official violations. See id. at 171 (concluding that Morrison is official national decision that "what men do to women in private will be beyond the reach of public authority").

The Court in Morrison also indicated that the states' lax enforcement of criminal and tort laws regarding violence against women did not distinguish this case from those present in Harris or the Civil Rights Cases. See Morrison, 529 U.S. at 621. The Court summarized Harris as invalidating $\$ 2$ of the Civil Rights Act of $1871-$ the "law exceeded Congress' $\$ 5$ power because the law was 'directed exclusively against the action of private persons, without reference to the laws of the State, or their administration by [its] officers." Morrison, 529 U.S. at 621 (quoting Harris, 106 U.S. at 640). The Court summarized the Civil Rights Cases as holding "that the public accommodation provisions of the Civil Rights Act of 1875, which applied to purely private conduct, were beyond the scope of the $\$ 5$ enforcement power." Id. The Court noted that both situations involved discriminatory state enforcement of existing state laws requiring equality of treatment. See id. (noting similarity be- 
turned. ${ }^{200}$

Section 13981 of VAWA, however, is not based on the notion that private actors who rape women violate women's Fourteenth Amendment rights. Congress found that state actors (not private actors) pervasively deny women equal protection by their discretionary decisions regarding complaints of violence motivated by gender animus. ${ }^{201}$ The discretionary decisions made by state actors such as police and prosecutors in their official capacities are state action. As the Supreme Court noted in 1948, "That the action of state courts and of judicial officers in their official capacities is to be regarded as action of the State within the meaning of the Fourteenth Amendment, is a proposition which has long been established by the decisions of this Court."202

Police and prosecutors' denial of equal protection to those women who do report deters the vast majority of other women from reporting violence motivated by gender animus that they suffer. Private violence does not violate the Fourteenth Amendment. But state action does, and the state action in this case also deters women from engaging the state itself. To remedy this problem, then, one cannot focus exclusively on those cases in which a woman reports that she was raped and then is dealt with unequally by state actors. For every one woman who reports having been raped and is dismissed, disbelieved or disgraced by state actors, there are four others who choose not to report to the police in an effort to avoid her fate. ${ }^{203}$ So legislation targeted at state actors would not remedy the problem. A more complete understanding of why a traditional state action analysis is inadequate when dealing with violence against women emerges with an analysis of the congruence and proportionality question under section 5 .

tween Harris and Civil Rights Cases). The Court also stated that the purpose of the Civil Rights Act of 1875 was the same as the purpose behind VAWA-for the federal government to step in where the states have failed. See id. (noting similarity between Civil Rights Act of 1875 and VAWA).

200. See Heart of Atlanta Motel, Inc. v. United States, 379 U.S. 241, 279 (1964) (Douglas, J., concurring) (stating preference for finding $\$ 5$ of Fourteenth Amendment as proper authority for Civil Rights Act of 1964); id. at 291 (Goldberg, J., concurring) (stating that Congress had power under both Commerce Clause and $\$ 5$ of Fourteenth Amendment to enact Civil Rights Act of 1964); Balkin, supra note 60, at A23 (arguing that Court's opinion in Civil Rights Cases was "overtly racist").

201. See S. ReP No. 102-197, at 43-44 (1991) (internal quotations omitted) (citing Gender Bias Task Force Reports from seventeen states). According to testimony:

"Study after study commissioned by the highest courts of the States ... has concluded that crimes disproportionately affecting women are often treated less seriously than comparable crimes against men. Collectively these reports provide overwhelming evidence that gender bias permeates the court system and that women are most often its victims." Id.

202. Shelley v. Kramer, 334 U.S. 1, 14 (1948). text.

203. For a discussion of this statistic, see supra note 174 and accompanying 


\section{B. Congruence and Proportionality}

The Supreme Court also held that Congress was not authorized to enact $\$ 13981$ under section 5 of the Fourteenth Amendment because the provision did not meet the "congruence and proportionality" requirements for legislation enacted under section 5.204 Under these requirements, Congress has no authority to change or redefine the substantive scope of what section 1 of the Fourteenth Amendment prohibits. ${ }^{205}$ The Supreme Court has held that the ability to define what section 1 prohibits resides within the exclusive province of the courts. ${ }^{206}$ By enacting $\S 13981$, however, Congress made no attempt to redefine the scope of what section 1 prohibits. ${ }^{207}$ Section 13981 of VAWA does not create or establish a right to equal protection against the actions of private individuals. Congressional findings supporting $\$ 13981$ of VAWA focused on the kind of state action that should be at the heart of the Fourteenth Amendment-unequal protection that is motivated by gender stereotype and bias. This is a section 1 problem caused by state action. By enacting $\S 13981$ of VAWA, Congress sought to redress the section 1 problem. VAWA did not define private violence against women as a violation of section 1 of the Fourteenth Amendment. Because states pervasively deny women equal protection against gender-motivated violence and further deter women from even reporting to them, federal suits against private individuals are the most appropriate remedy under the Fourteenth Amendment. Thus, $\S 13981$ of VAWA operates under section 5 in order to remedy the section 1 violation.

For remedial legislation under section 5 of the Fourteenth Amendment to be congruent and proportional, the Supreme Court has emphasized that it must "be adapted to the mischief and wrong which the [Fourteenth] Amendment was intended to provide against." ${ }^{208}$ The Court clarified that the "appropriateness of remedial measures must be considered in light of the evil presented."209 In terms of violence against

204. See Morrison, 529 U.S. at $625-26$ (stating that $\$ 13981$ does not meet congruence and proportionality test).

205. See Kimel v. Fla. Bd. of Regents, 528 U.S. 62, 81 (2000) (stating that Congress is not authorized to define what Constitution prohibits); Fla. Prepaid Postsecondary Educ. Expense Bd. v. Coll. Sav. Bank, 527 U.S. 627, 639 (1999) (same); City of Boerne v. Flores, 521 U.S. 507, 519 (1997) ("Congress has [no] power to decree the substance of the Fourteenth Amendment's restrictions on the states.").

206. See Morrison, 529 U.S. at 620 (noting that Congress is limited in its power under section 5 of Fourteenth Amendment).

207. See Violence Against Women, supra note 64 , at $\$ 6: 24$. Cass Sunsein argues that VAWA's civil rights provision did not redefine the substantive prohibitions of the Fourteenth Amendment. Congress found that victims of gendermotivated crimes were denied equal protection by bias and discrimination in the criminal justice system. Correcting this differential treatment arising out of gender discrimination is clearly a Fourteenth Amendment concern. See id.

208. Flores, 521 U.S. at 532 (quoting Civil Rights Cases, 109 U.S. at 13).

209. Id. at 530. The context of the problem that Congress is addressing is important to the judicial analysis of the legislative remedy because "[s]trong mea- 
women, the "mischief and wrong" that the Fourteenth Amendment was intended to provide against is the unequal protection states afford women against rape and battery. ${ }^{210}$ Here, the "evil presented" is the pervasive lack of legal remedy women have for the gender-motivated violence they suffer. Women believe, with good reason, that the state will not provide them with equal protection and so do not report having been assaulted to the police. The remedy, then, has to be adapted to that mischief.

The Court in Morrison indicated that the most appropriate remedy would be for rape victims to sue those state actors who deny them equal protection. ${ }^{211}$ Limiting relief to suits against state actors would be underinclusive, as well as incongruent and disproportionate to the evil presented, because it would provide potential relief only to those sixteen percent of rape victims who report having been raped to the police and who are denied equal protection. A congruent and proportional remedy to the evil presented would provide potential relief to the vast majority of rape victims, those eighty-four percent of rape victims who do not report having been raped to the police. These victims are deterred from reporting because of state action.

The most congruent and proportional remedy, then, is to afford women the opportunity to pursue legal relief against their abusers in federal court. Giving victims the ability to sue in federal court is adapted to the evil presented that women have no legal remedy at the state level. As Senator Joseph Biden, author of VAWA, argued, "Section 13981 is calibrated precisely to address the very constitutional violation that Congress identified-the states' failure to afford victims of gender-based violence an opportunity to vindicate their rights on par with other victims of serious violent crime." 212 Here, a remedy against private actors is particularly appropriate when chronic bad action on the part of the state deters women from engaging the state, despite suffering gender-motivated violent crime.

The Morrison Court, however, declared that $\$ 13981$ of VAWA was not congruent and proportional because it "visits no consequence whatever on any Virginia public official involved in investigating or prosecuting Brzonkala's assault." 213 Limiting relief to suing state actors is unnecessa-

sures appropriate to address one harm may be an unwarranted response to another, lesser one." Id. Although not determinative, a legislative record showing that Congress "respond[ed] to a history of "widespread and persisting deprivation of constitutional rights' of the sort Congress has faced in enacting proper prophylactic section five legislation" may lead a court to determine that the legislation is a constitutional exercise of Congress' section 5 authority. College Savings Bank, 527 U.S. at 646 (quoting Flores, 521 U.S. at 526).

210. See generally, Jennifer S. Hendricks, Women and the Promise of Equal Citizenship, 8 TEx. J. Women \& L. 51 (1998) (encouraging Congress to utilize power under section 5 of the Fourteenth Amendment to promote equal citizenship for women).

211. See Morrison, 529 U.S. at 626 (stating that $\$ 13981$ 's civil remedy was deficient because it was "not aimed at proscribing discrimination by [state] officials").

212. Biden, supra note 59 , at 40 .

213. Morrison, 529 U.S. at 626. 
rily severe, however, because it would require a woman to report a rape to the police first-a prospect most rape victims dread-before she could have a claim under section 1 or an authorized remedy under section 5 . Because states deter reporting by their bad actions when women do report, reporting itself should not be a prerequisite for obtaining relief under section 5. Rational actors respond to the prospect of futile engagement with the state. It cannot be that when a state is so bad that it deters victims' engagement with the formal mechanisms of police power the state thereby manages to circumvent the state action requirement of the Fourteenth Amendment.

Moreover, women already can sue state actors for violations of their equal protection rights, namely under $\S 1983 .{ }^{214}$ By and large, when they make these claims, they do not win. The limited potential relief under $\S 1983$ reveals why suits against state actors are incongruent and disproportionate to the section 1 violation here. To make a $\$ 1983$ claim, a victim must allege a violation of the Constitution under color of state law. ${ }^{215}$ Because most women do not report having been raped by state actors, they have no state actor to sue under $\$ 1983$. Individual claims against state actors would only provide potential relief for those women who fall within the exception, not the rule. Even for the exceptional victim who does report, it is difficult to bring claims against individual state actors who function with broad discretion. Ostensibly neutral discretionary decisions by police and prosecutors hide intent-bias against women that is grounded in the historical common law of rape. As Senator Biden argued, "an individualized showing of state constitutional violations in each and every case would have imposed an undue-and likely impossible-burden of proof on the very victims whose access to the legal system Congress intended to ease, not restrict." 216

Finally, even if suits against state actors were congruent and proportional, suits against private actors also still would be congruent and proportional to the section 1 violation. ${ }^{217}$ Under the text of section 5, Congress has the authority to implement all "appropriate" remedial legislation.

\section{National Problem}

Independent of the state action and the congruence and proportionality doctrines, the United States Supreme Court also ruled in Morrison that $\S 13981$ was unconstitutional remedial legislation because $\S 13981$ applied uniformly across the nation, despite the fact that, as the Court put it,

214. See 42 U.S.C. $§ 1983$ (2001).

215. See id. (creating cause of action for deprivation of "rights, privileges, or immunities secured by the Constitution").

216. Biden, supra note 59 , at 42 .

217. See generally Evan H. Caminker, Symposium on New Directions in Federalism: Private Remedies for Public Wrongs Under Section 5, 33 Loy. L.A. L. Rev. 1351 (2000) ("Section 5's language does not limit Congress's potential regulatory targets."). 
"Congress' findings indicate that the problem of discrimination against the victims of gender-motivated crimes does not exist in all States, or even most States." 218 The Court did not provide any support for this assertion. The assertion was not how Congress saw the problem. Congress saw states' denial of equal protection against gender-motivated violence as a pervasive, national problem. ${ }^{219}$

But the Court's statement may reveal the limited nature of what it was willing to consider a section 1 violation. What, exactly, was the Court referring to as "the problem of discrimination against the victims of gendermotivated crimes" that, it said, "does not exist in all States, or even most States?"220 In all likelihood, it was referring to the biased common law rules in rape law, including the marital rape exemption, which no longer formally exists in all states or even most states. ${ }^{221}$ The Court was looking at state criminal codes for evidence of discrimination that violated section 1 of the Fourteenth Amendment. ${ }^{222}$ Because most states have made significant changes in their rape codes, including abolishing the marital rape exemption, the Court likely concluded there is no nationwide denial of equal protection.

Such a conclusion, however, is unduly formalistic. Evidence that women are denied equal protection cannot be gleaned exclusively from statute books. Equal protection refers not only to the criminal code. It refers to the decisions by state actors in their jobs that go beyond the written law. As the Supreme Court has explained, "state action in violation of the Amendment's provisions is equally repugnant to the constitutional commands whether directed by state statute or taken by a judicial official in the absence of a statute." ${ }^{223}$ Discretionary decisions by state actors constitute state action and can violate section 1 just as a discriminatory code would. Although states have cleaned up their acts on paper, when one looks at the discretionary decisions by state actors nationwide, a picture of prejudiced intransigence regarding violence against women re-emerges. That intransigence is a national problem, regardless of variations in state codes, and it violates section 1 .

218. Morrison, 529 U.S. at 626.

219. See S. Rep No. 102-97, at 43-44 (1991) (internal quotations omitted) (citing Gender Bias Task Force Reports from seventeen states). According to testimony, "[s] tudy after study commissioned by the highest courts of the States ... has concluded that crimes disproportionately affecting women are often treated less seriously than comparable crimes against men. Collectively these reports provide overwhelming evidence that gender bias permeates the court system and that women are most often its victims." Id.

220. Morrison, 529 U.S. at 626.

221. For a discussion of the marital rape exemption, see supra notes $96-98$ and accompanying text.

222. See Morrison, 529 U.S. at 625 (scrutinizing state criminal laws).

223. Shelley v. Kramer, 334 U.S. 1, 16 (1948). 


\section{Federalism}

There are federalism concerns raised by $\S 13981$ of VAWA. ${ }^{224}$ In the United States, the authority of the federal government is one of enumerated powers and is limited to the powers specifically granted to it by the United States Constitution. The state governments, however, hold a more general police power to protect the health, safety and general welfare of state residents. A state action is invalid only if it violates a limitation imposed by the Constitution. Issues of federalism arise when either a state government or the national government acts outside its respective sphere of power.

Federalism-based limits on the national government protect jurisdictional values and sovereignty values. ${ }^{225}$ The jurisdictional values, addressing the division of lawmaking authority between the federal and state governments, protect the states from federal intrusion into areas of states' "proper sphere of exclusive regulatory jurisdiction."226 Sovereignty values, concerning relations between the federal government and states, protect "the states' status and dignity as a co-equal and original sovereign."227 Section 13981 of VAWA violates neither the jurisdictional nor the sovereignty principles of federalism. ${ }^{228}$

224. The value of federalism as interpreted by the Court has been criticized. See, e.g., MacKinnon, supra note 63, at 136 (criticizing Morrison Court's "specific notion of federalism"). MacKinnon observes that deference to federalism is especially odious in regard to equality rights because women did not contribute to the configuration of federalism's hierarchy with the inviolable "private" being a subprovince of the "local." See id. at 169 (observing that federalism's distrust of centralized power was arranged before women had political voice). Federalism speaks in the voice of men who trust their own power but not the power of other men over them. See id. (referring to Fourth Circuit's preamble finding VAWA unconstitutional). The experience of women, and other subordinated groups, is not to distrust centralized power but to distrust the system of limited and dispersed power that has preserved their inequality. See $i d$. (analogizing to experience of African Americans whose slavery was maintained by "states' rights").

225. See Caminker, supra note 217 , at $1364-65$ (discussing structural principles of federalism). Federalism also protects the "effectiveness of both state and federal governments as representative bodies ...." Brzonkala v. Va. Polytech Inst. \& State Univ., 169 F.3d 820, 927 (4th Cir. 1999) (Motz, J., dissenting) (arguing that political accountability of elected officials "suffers when citizens are confused about which sphere of government is responsible for the regulation of an activity") (citing New York v. United States, 505 U.S. 144, 168 (1992)). Judge Motz concluded that $\$ 13981$, "which legislates in an area of traditional congressional expertise, and does not interfere with or usurp any state authority, fits comfortably within the proper federalism-based limits on Congress's Commerce Clause power." Id. at 925.

226. Caminker, supra note 217 , at 1364 .

227. Id. at 136465 .

228. See id. at 1359 ("Private remediation for unconstitutional state action is consistent with the constitutional text, Supreme Court precedent, and principles of federalism that appropriately guide Section 5's interpretation."). 
Congress included substantial procedural limits on $\S 13981$ of VAWA. ${ }^{229}$ In response to federalism concerns raised by both federal and state judges, Congress defined the concurrent federal and state jurisdiction permitted under VAWA, limited removal jurisdiction under the statute and barred federal courts from exercising pendent jurisdiction over related state law claims that involved traditional family law matters. ${ }^{230}$

Given what Congress found about the violation of section 1, it could have intruded more heavily on state turf by, for instance, scaling back the doctrines of immunity under $\S 1983$. $^{231}$ Pursuant to section 5 of the Fourteenth Amendment, Congress may have been able to prohibit discriminatory state enforcement of facially neutral laws and authorize a wider scope of actions for damages against the states or state officials. ${ }^{232}$ Allowing suits in federal courts against private actors is much less disruptive to state lawmaking authority than the congressional regulation of state conduct would have been. ${ }^{233}$

For instance, $\S 13981$ of VAWA threatens the status and dignity of the states less than the decision to diminish the immunity doctrines of

229. See generally, Nourse, Where Violence, supra note 59, at 282-92 (providing detailed legislative history of VAWA).

230. See id. at 283-84 (discussing procedural limitations of VAWA). These procedural limits initially were designed by the Senate Judiciary Committee. See id. (same); Mackinnon, supra note 63, at 136 (stating that Morrison is "high-water mark" to date of Supreme Court jurisprudence deferring to notions of federalism). VAWA did not duplicate state law in theory, design or remedy; rather, it granted federalism friendly concurrent jurisdiction. See Mackinnon, supra note 63, at 149 (noting that VAWA only supplemented civil options while leaving state criminal remedies in place).

231. See Biden, supra note 59, at 40-41 (suggesting alternative course Congress could have taken in drafting portions of $\$ 13981$ ). Biden stated:

Congress was not required ... to enact a far more sweeping and intrusive remedy for state failings, such as preempting the states' criminal and tort laws altogether, authorizing lawsuits directly against states or their officials, extending federal jurisdiction over family law matters, denying state's concurrent jurisdiction over actions brought under $\$ 13981$, or by regulating all violence against women, regardless of the presence or absence of gender-based animus.

Id.

232. See id. (stating that Congress could have taken different approach to regulate conduct of states and state actors).

233. See Caminker, supra note 217, at 1366 (arguing that evaluation of congressional interference with state police power should not turn on whether remediation scheme is aimed at public or private actors). Caminker states:

$[T]$ he potential preemptive scope of private remediation is no greater than the potential preemptive scope of conventional public remediation. It is true that congressional regulation of private conduct can, and often does, trump state law and thereby displace the state's erstwhile regulatory role. But congressional regulation of state conduct does much the same thing.

Id.; see also id. at 1367-68 (hypothesizing that states would be forced to alter enforcement of their laws to achieve equal protection for men and women). 
$\S 1983 .{ }^{234}$ Facilitating more suits against the state might invite federal judicial scrutiny into state law enforcement activities, resulting in injunctions or federal supervision of state authorities. ${ }^{235}$ Because $\S 13981$ of VAWA is less intrusive into states' spheres of power than congressional alternatives, it does not infringe on any of the core concerns of federalism. As between authorizing suits against private individuals and authorizing those against state actors, $\S 13981$. of VAWA chose the alternative that is kinder to the states.

If one prizes federalism and states interests, one should applaud $\S 13981$ of VAWA. Remedies against assailants do not infringe on any of the core concerns of federalism. In fact, VAWA treaded lightly on the states and did not threaten their status or dignity. It is no wonder that thirty-six states agreed, signing a brief in support of $\S 13981$ of VAWA. ${ }^{236}$

\section{Conclusion}

The Morrison case is over and women lost. ${ }^{237}$ But that fact points to the reality that a re-evaluation of the state action doctrine under section 5 of the Fourteenth Amendment is now in order. When states act to deny women equal protection over time by ignoring or dismissing violence that is motivated by gender animus, women rationally have no faith that the state will take the violence against them seriously. The state is not where

234. See id. at 1370 ("Section 5 public remediation poses absolutely no threat whatsoever to the status/dignitary values underlying recent federalism decisions. But, of course, private remediation by definition also poses absolutely no threat to these values."). state).

235. See id. (suggesting consequences of allowing additional suits against

236. See Brief of the States of Arizona, Alaska, Arkansas, California, Colorado, Connecticut, Delaware, Georgia, Hawaii, Illinois, Iowa, Kansas, Kęntucky, Louisiana, Maine, Maryland, Minnesota, Mississippi, Missouri, Montana, Nevada, New Hampshire, New Mexico, New York, North Carolina, North Dakota, Oklahoma, Oregon, Rhode Island, Tennessee, Utah, Vermont, Washington, West Virginia and Wisconsin, and the Commonwealths of Massachusetts and Puerto Rico, as Amici Curiae in Support of Petitioners' Brief on the Merits, United States v. Morrison, 529 U.S. 598 (2000) (Nos. 99-5, 99-29) (advocating remedial scheme of $\$ 13981$ ).

237. As Catherine Mackinnon puts it,

[A] gainst an historical backdrop of the use of federalism to deny racial equality and enforce white supremacy, Morrison can be seen to employ ostensibly gender-neutral tools to achieve substantive victory for the social institution of male dominance. Read substantively, Morrison is not an abstract application of neutral institutional priorities, but a refusal to allow Congress to redress violence against women .... .

Mackinnon, supra note 63, at 136 . She goes on to say that, In Morrison, the Court revived and deployed against women the odious "states' rights" doctrine, the principal legal argument for the maintenance of slavery . . . . Combined with the Court's equal protection jurisprudence[,] . $\therefore$ Morrison leaves women who are denied the equal protection of criminal laws against battering and rape without adequate Id. legal recourse. 
most women turn when they are sexually violated, primarily because women do not want to be hurt even more. They do not want to face the disbelief, accusations of guilt and disregard they have come to expect from state actors. The vast majority of women do not report to police the sexual violence they suffer. Even when women do not report, however, states have acted to deny those women equal protection because of what happened before. This insight is what a re-evaluation of the interaction between the state and victims of sexual violence reveals.

Allowing those relatively few women who do report to sue state actors will not help those women, much greater in number, whose rights are also violated by bad state actions who choose not to report. Such a narrow solution, suggested by the Court in Morrison, will not address the broader reality of women's lack of a legal remedy for the sexual violence they suffer. Only allowing women to make claims in federal court against private actors who commit gender-motivated violence would provide women with a remedy that is congruent and proportional to the violation of the Fourteenth Amendment that women suffer.

Critics might argue that I am proposing an end-run around the normal rules applicable to section 5 legislation. Sexual violence, however, is a context in which citizens interact with legal actors in a way that is particularly sensitive to the prospect of futile engagement with the state. When viewed in this light, the normal rules of what Congress can reach must be re-evaluated, and narrow prescriptions that are no better than the status quo will not suffice. 